Tomasz Kornecki

\title{
Główne czynniki zmian w procesie internalizacji wartości w ponowoczesnej rodzinie i różnych jej odmianach
}

Pierwsza połowa XXI stulecia charakteryzuje się istotnym odejściem od zasad przyjmowanych przez wieki zarówno przez pojedyncze osoby, jak i wspólnoty, w tym wspólnotę rodziny. Dotyczy to nie tylko relacji między członkami tej komórki społecznej, ale także coraz bardziej typowych dla naszych czasów problemów, jakie dotykają rodzinę, pochodzących z zewnątrz. Rodzina w dzisiejszych czasach potrzebuje z jednej strony motywowania (przede wszystkim dostrzegania) jej podstaw o charakterze antropologicznym, $\mathrm{z}$ drugiej natomiast zaufania ze strony działania władz krajowych i międzynarodowych w stosunku do niej - pod względem ekonomicznym, finansowym ${ }^{1}$, wychowawczym, wspierającym itd. A zatem na pierwsze miejsce wysuwa się polityka prorodzinna jako element polityki skierowanej w stronę rodziny, dalej rola kobiety w zmieniającym się świecie, sprawa eurosieroctwa, kwestia związana ze zwiększającą się liczbą rozwodów oraz tolerancją obyczajową. Wszystko to łączy się ze zmieniającym się systemem wartości dotyczących rodziny.

1 Por. C. Migliore, Wystapienie wprowadzające, w: Rodzina we wspótczesnej Europie. Rola Kościoła katolickiego w procesie integracji europejskiej, red. R. Budnik, M. Góra, Gliwice 2014, s. 32. 


\section{Meandry polityki prorodzinnej we współczesnym świecie}

Głównym założeniem polityki oraz działania polityków powinna być troska o dobro wspólne zabezpieczające dobro każdej osoby ${ }^{2}$. Wszędzie tam, gdzie jest i funkcjonuje osoba ludzka, gdzie wykazuje ona swoją aktywność, rozwój, zaangażowanie, powinna się również pojawiać polityka otwarta na człowieka i służąca mu. Chodzi tutaj o takie kwestie jak ekonomika, gospodarka, ustrój społeczny, prawo, medycyna, nauka (zarówno na etapie podstawowym, średnim, jak i wyższym), religia i wreszcie rodzina $\mathrm{z}$ całą jej specyfiką ${ }^{3}$ a więc o cały wymiar panowania nad światem, który jest zadaniem i łączy się z odpowiedzialnością ${ }^{4}$. Wszędzie tam, jak również w innych wymiarach życia, których wymienienie jest niemożliwe ze względu na tematykę pracy związaną ściśle z rodziną, polityka powinna uwzględniać to, co nazywamy podmiotowością człowieka, jego wolnością, a tym samym winna szanować jego wybór.

Zdajemy sobie sprawę, że nie zawsze tak było, czego przykładem są chociażby systemy totalitarne, gdzie dobro było rozumiane z perspektywy tych, którzy za tymi systemami się opowiadali. Jan Paweł Il pisał, że:

Podstawowym kryterium polityki uprawianej na rzecz osoby i społeczeństwa jest dążenie do wspólnego dobra jako dobra wszystkich ludzi i całego człowieka, dobra, które jest dane i które gwarantuje, że jego przyjęcie jest sprawą wolnego i odpowiedzialnego wyboru poszczególnych osób czy stowarzyszeń: „Wspólnota polityczna - czytamy w konstytucji Gaudium et spes - istnieje więc dla dobra wspólnego, w którym znajduje ona pełne uzasadnienie i sens i z którego bierze swoje pierwotne i sobie właściwe prawo. Dobro zaś wspólne obejmuje sumę tych warunków życia społecznego, dzięki którym jednostki, rodziny i zrzeszenia mogą pełniej i łatwiej osiągnąć swoją własną doskonałość". Ponadto polityka na rzecz osoby i społeczeństwa przyjmuje jako staly kierunek postępowania obronę i promocje sprawiedliwości, rozumiane jako „cnota”, w której wszyscy winni być

2 Por. Jan Paweł II, Przemówienie w Parlamencie, Warszawa, 11 czerwca 1999, w: Jan Paweł Il, Pielgrzymki do Ojczyzny. Przemówienia, homilie, Kraków 1999, s. 1083.

3 Por. L. Dyczewski, Więź między pokoleniami w rodzinie, Lublin 2002, s. 11.

4 Por. VS 38. 
wychowywani, i jako „siła” moralna, która wspiera zaangażowanie na rzecz praw i obowiązków każdego i wszystkich, mając za podstawę osobistą godność ludzkiej istoty ${ }^{5}$.

A zatem polityka, by mogła służyć zarówno pojedynczemu człowiekowi, jak i dobru wspólnemu, winna opierać się na moralności, zasadach niezmiennych i dotyczących wszystkich - tych, którzy rządy sprawują, i tych, wobec których owe rządy są sprawowane. Nie można mówić o polityce tam, gdzie brakuje w działaniach polityków, ale również w systemach państw, podstawowej wartości, jaką jest sprawiedliwość. Życie człowieka w jego relacjach wobec innych nie będzie nigdy w sposób odpowiedni zbudowane, jeżeli nie oprze się go na jednym $\mathrm{z}$ tych podstawowych fundamentów. A zatem oddanie tego, co się komuś należy, dotyka z jednej strony pojedynczego człowieka, z drugiej natomiast grupę ludzi, w tym rodzinę.

Spośród różnych i wielu rodzajów polityki można mówić o tzw. polityce prorodzinnej. Jeżeli wróci się do definicji polityki jako troski o dobro drugiego człowieka, wówczas - mówiąc o polityce prorodzinnej stwierdzi się, że jest ona troską o człowieka w rodzinie i o całą rodzinę jako wspólnotę. W Polsce obowiązek ten ciąży na trzech podmiotach władzy - na prezydencie RP, który będąc strażnikiem Konstytucji ${ }^{6}$, winien wypełniać jej regulacje dotyczące rodziny, oczywiście w zakresie swoich prerogatyw ${ }^{7}$; na władzy ustawodawczej - chodzi tutaj o sejm i senat $^{8}$ - której zadaniem jest uchwalanie odpowiednich, słusznych dla rodziny ustaw. Należy dodać, iż spośród tych dwóch izb kontrolę nad Radą Ministrów sprawuje jedynie sejm, w tym zakresie, który jest określony przepisami zarówno ustawy zasadniczej, jak i poszczególnych ustaw 9 . Odpowiedzialność za politykę prorodzinną w szczególny sposób spoczywa na premierze i podległym mu ministrom. Wreszcie obowiązek, o którym mowa, ciąży również na władzy sądowniczej. Chodzi tu przede wszystkim o wydawanie takich orzeczeń, które nie będą krzywdziły

\footnotetext{
5 CHL 42.

6 Por. art. 126 \& 2 KRP.

7 Por. art. $126 \int 3$ KRP.

8 Por. Polskie prawo konstytucyjne, red. W. Skrzydło, wyd. 5, Lublin 2000, s. 240.

9 Por. Polskie prawo konstytucyjne..., dz. cyt., s. 238.
} 
rodziny oraz jej poszczególnych członków. Znane są jednak przypadki ${ }^{10}$, gdy sądy w imieniu państwa polskiego odbierają dzieci rodzicom, skazując tak jednych, jak i drugich na dramat związany z rozdzieleniem tych, którzy najbardziej się kochają. Chodzi tutaj o te sytuacje, w których nie występują ani przemoc domowa, ani alkoholizm czy inny rodzaj demoralizacji dzieci. Tym samym polityka prorodzinna państwa nie jest realizowana bądź też jest realizowana w sposób wypaczony.

Oczywiście należy podkreślić, iż istnieją przypadki, gdy dzieci zagrożone są demoralizacją $w$ rodzinnym domu. Warto zwrócić uwagę na fakt, że częściej alkohol spożywają mężczyźni niż kobiety, a rodzina, w której pojawiają się problemy alkoholowe, narażona jest chociażby na pozbawione ciepła relacje, niekiedy charakteryzujące się brutalnością. W wyniku alkoholizmu ulegają zaburzeniu elementarne funkcje rodziny ${ }^{11}$. Dlatego też powinny być podejmowane odpowiednie działania ze strony państwa. Polityka prorodzinna $\mathrm{w}$ takich przypadkach musi być nastawiona m.in. na przeciwdziałanie alkoholizmowi i sięganie do jego źródeł, a więc przyczyn, z których powodu pojawia się u poszczególnych osób ten nałóg, oraz ich likwidacja - tam gdzie jest to możliwe. Oczywiście niekiedy źródłami alkoholizmu są uwarunkowania wewnątrz samej rodziny, pewne predyspozycje danej osoby itd. Jednak jest i tak, że alkoholizm pojawia się w momencie, kiedy któryś z małżonków traci pracę, gdy nie może jej znaleźć, wówczas gdy otrzymuje zbyt niskie wynagrodzenie czy też jest źle traktowany w miejscu pracy. Warto podkreślić, iż na wszystkie wyżej wymienione czynniki państwo ma wpływ i może prowadzić taką politykę, która będzie zmniejszała bezrobocie i sprawiała, że zarobki ulegną podwyższeniu. Należy również zauważyć, iż w rodzinach dotkniętych nałogiem alkoholizmu państwo powinno stawać zawsze po stronie osób poszkodowanych przez alkoholików, a więc dzieci i najczęściej kobiet.

Kolejnym problemem współczesnej polskiej rodziny jest emigracja zarobkowa. Tutaj również państwo winno prowadzić politykę, dzięki której rodziny mogłyby pozostać razem w kraju bez konieczności wyjazdu w celu pracy poza granicę Polski. Niezwykle istotną kwestią jest

10 Stan na pierwszą połowę 2015.

11 Por. W. Majkowski, Rodzina polska w kontekście nowych uwarunkowań, Kraków 2010, s. 245. 
również dbanie o odpowiedni przyrost naturalny. Jeszcze w drugiej połowie lat 90. ubiegłego wieku Główny Urząd Statystyczny przewidywał, iż w Polsce w roku 2010 liczba ludności wyniesie 40,2 mln osób ${ }^{12}$. Pomimo tych, jak się wydaje z perspektywy czasu, optymistycznych przewidywań liczba osób w Polsce jest o wiele niższa. Wiąże się to ze stosunkowo niską od kilku lat liczbą urodzeń. Tendencja ta utrzymuje się od roku 1984, kiedy to rozpoczął się spadek liczby urodzeń. W 1996 roku liczba ta wyniosła 428,2 tys. urodzeń żywych, natomiast rok później już tylko 412 tys. ${ }^{13}$ Widać zatem, że od połowy lat 80 . mamy do czynienia z malejącą liczbą urodzeń dzieci. Ta tendencja mimo zmian ustrojowych utrzymała się do tego stopnia, że liczba dzieci, które urodziły się od 1989 roku, nie jest w stanie zapewnić tego, co określa się jako "odtwarzanie" ludności ${ }^{14}$. Oznacza to, że Polacy zamieszkujący teren Rzeczypospolitej Polskiej są narodem starzejącym się, co wpływa negatywnie zarówno na istnienie biologiczne narodu, jak również na ekonomikę, gospodarkę, a tym samym politykę. Przykład ten wskazuje, że z jednej strony polityka związana jest z życiem rodzinnym, ale z drugiej to rodzina ma istotny wpływ na kwestie powiązane z polityką. Widać zatem, iż system polityczny i ekonomiczny, który pojawił się w Polsce po $1989 \mathrm{roku}$, nie był do tej pory ${ }^{15} \mathrm{w}$ stanie $\mathrm{w}$ realny sposób zapewnić polityki prorodzinnej, poza nielicznymi wyjątkami. Charakterystyczny jest jednak fakt, iż Polki stanowią drugą co do wielkości, jeżeli chodzi o liczbę urodzeń dzieci, grupę w Wielkiej Brytanii. To wskazuje, że tam, gdzie system ekonomiczny i polityczny jest odpowiedni i otwarty na rodzinę, w tym na narodziny nowych obywateli, następuje również wysoki przyrost naturalny wśród Polaków.

Należy podkreślić, iż istnieje w Polsce potrzeba odbudowy polityki prorodzinnej, co wobec licznych zaniedbań nie jest sprawą łatwą, jak również, co ważne, nie jest kwestią krótkoterminową. Taką odbudowę ze względu na zaangażowanie środków ekonomicznych i społecznych trzeba rozłożyć na wiele lat. Nie jest bowiem możliwe w przeciągu jednego roku czy też kilku miesięcy wprowadzenie takich zmian, które

12 Por. Pełnomocnik Rządu do Spraw Rodziny, Raport o sytuacji polskich rodzin, Warszawa 1998, s. 17.

13 Por. Pełnomocnik Rządu do Spraw Rodziny, Raport o sytuacji polskich..., dz. cyt., s. 29.

14 Por. Pełnomocnik Rządu do Spraw Rodziny, Raport o sytuacji polskich..., dz. cyt., s. 30.

15 Stan na rok 2015. 
przyniosłyby natychmiastowe efekty, gdyż polityka prorodzinna związana jest $\mathrm{z}$ innymi gałęziami polityki i od nich uzależniona, a oprócz tego wpływa też na relacje między członkami rodziny, ponieważ więź rodzinna tworzona jest na podstawie wielu czynników ${ }^{16}$, również polityki prorodzinnej.

Z pomocą w prowadzeniu polityki prorodzinnej przychodzą Kościół katolicki i Stolica Apostolska. Kwestia tej właśnie polityki była bliska zarówno Ojcu Świętemu Janowi Pawłowi Il, jak również Benedyktowi XVI, i jest bliska papieżowi Franciszkowi. W roku 1983 powstał w Watykanie dokument (jest to czas pontyfikatu papieża Polaka) zatytułowany Karta Praw Rodziny. Już sam tytuł sugeruje, iż ze strony życia społecznego i państwowego powinny być przestrzegane prawa rodziny. Artykuł 6 Karty stanowi:

Rodzina ma prawo istnieć i rozwijać się jako rodzina. Władze publiczne winny uznawać i wspierać godność, słuszną niezależność, intymność, integralność i stałość każdej rodziny ${ }^{17}$.

Pierwszą, elementarną kwestią związaną z rodziną, jakiej wymaga od państwa polityka prorodzinna, jest możliwość fizycznego istnienia rodziny, a co z tym jest związane - władze publiczne powinny dać poszczególnym osobom możliwość zakładania rodzin według własnego uznania, szanując wolność wyboru przyszłego małżonka, dalej szanując godność tejże rodziny, czyli godność każdego z jej członków, jak również godność wspólnotową, jaka występuje w tej najmniejszej tkance społecznej. Szacunek wobec godności rodziny to otwarcie na wybór drogi, jaką ta rodzina chce przejść, otwarcie na wartości, jakie reprezentuje, w tym wartości religijne, wartości, według których zamierza wpływać na przyszłe pokolenia, wychowując je. Z kolei niezależność rodziny polega na tym, by z jednej strony mogła ona liczyć na pomoc państwa wówczas, gdy tej pomocy potrzebują jej poszczególni członkowie i ona sama jako wspólnota, $\mathrm{z}$ drugiej natomiast - by państwo nie ingerowało zbyt mocno w jej wewnętrzną strukturę.

16 Por. L. Dyczewski, Więź między..., dz. cyt., s. 15.

17 Art. 6 KPR. 
Mimo iż będzie to stanowiło przedmiot dalszej części opracowania, już tutaj warto wskazać na sprawę integralności rodziny. Podstawowym zadaniem państwa jest to, by podejmować takie działania, które bez względu na zmieniające się warunki ekonomiczne, społeczne i gospodarcze sprawią, że członkowie rodziny będą ze sobą integralnie zjednoczeni, tworząc wyjątkową wspólnotę. Polityka prorodzinna państwa, o czym wspomniano wyżej, winna także przestrzegać zasad religijnych i umożliwiać poszczególnym rodzinom nie tylko prowadzenie, ale i rozwój życia religijnego. Artykuł 7 Karty Praw Rodziny stanowi:

Każdej rodzinie przysługuje uprawnienie do swobodnego organizowania życia religijnego w ognisku domowym pod kierunkiem rodziców, jak również prawo do publicznego wykonywania i głoszenia swojej wiary, uczestniczenia w kulcie publicznym oraz swobodnego wyboru programów wychowania religijnego, bez znoszenia $\mathrm{z}$ tego powodu jakiejkolwiek dyskryminacji ${ }^{18}$.

A zatem życie religijne rodziny powinno być możliwe przynajmniej w dwojakim stopniu: zarówno w domu, w miejscu, w którym rodzina przebywa wspólnie, prowadząc swoje życie codzienne, jak i poza nim chodzi tu o sprawowanie kultu publicznego, np. podczas nabożeństw w kościołach czy też poza nim, jak chociażby w czasie procesji Bożego Ciała, ale także podczas przebywania w szkole, gdzie powinno być zapewnione nauczanie religii dla tych osób, które chcą uczestniczyć w katechezie. Nie we wszystkich krajach publiczne szkolnictwo zapewnia dostęp do lekcji religii, a w Polsce istnieją ugrupowania polityczne, które opowiadają się za usunięciem lekcji katechezy ze szkół.

Wreszcie warto poruszyć sprawę konkretnych zadań, jakich rodziny mają prawo oczekiwać ze strony władz państwowych. Karta bowiem podkreśla, że rodzina jest podstawą życia o charakterze społecznym ${ }^{19}$, a ponadto:

18 Art. 7 KPR.

19 Por. L. Drzewiecki, Rodzina Karty Praw Rodziny w kontekście społeczeństwa polskiego, w: Rodzina w zmieniającym się społeczeństwie, red. P. Kryczka, Lublin 1997, s. 141. 
Rodziny mają prawo oczekiwać od władz publicznych właściwej, nikogo niedyskryminującej polityki rodzinnej w kwestiach prawnych, gospodarczych, społecznych i finansowych. Rodziny mają prawo do takich warunków ekonomicznych, które im zagwarantują odpowiadający ich godności poziom życia i pełny rozwój. Nie wolno pozbawiać ich prawa do nabywania i posiadania dóbr prywatnych, które sprzyjałyby stabilizacji życia rodzinnego; prawa dotyczące dziedziczenia i przekazywania majątku winny respektować potrzeby i uprawnienia członków rodziny. Rodziny mają prawo spodziewać się, że społeczeństwo, przewidując ich potrzeby, zapewni im pomoc w nadzwyczajnych wypadkach, takich jak: przedwczesna śmierć jednego lub obojga rodziców, opuszczenie rodziny przez jednego z małżonków, w razie wypadku, choroby czy inwalidztwa, w razie bezrobocia lub wtedy, gdy rodzina musi ponosić dodatkowe ciężary związane ze starością, niedorozwojem fizycznym czy umysłowym któregoś ze swych członków, czy też w związku z wychowywaniem dzieci ${ }^{20}$.

Z powyższego cytatu wynikają najbardziej istotne kwestie, na których powinna się skupiać polityka prorodzinna każdego państwa, niezależnie od tego, na jakim etapie rozwoju to państwo się znajduje. Polityka ta musi dotyczyć szerokiego wachlarza zagadnień, począwszy od prawa stanowionego aż po gospodarkę. Rodzina, jak i każdy z jej członków $\mathrm{z}$ osobna, ma prawo do posiadania rzeczy materialnych i ochrony tego prawa przez państwo, także w wymiarze dziedziczenia. Pojęcie spadku należy do grupy pojęć podstawowych, gdyż określa zarówno prawa, jak i obowiązki cywilne o charakterze majątkowym zmarłego, które przechodzą na jego spadkobierców. Pojęcie to określa również granice odpowiedzialności spadkobierców, jaką ponoszą za długi spadkowe, oraz stanowi o wysokości zachowków ${ }^{21}$. W sensie materialnym dziedziczenie jest uzewnętrznieniem relacji rodzinnych zachodzących np. między dziećmi a rodzicami.

Wreszcie państwo w działaniach polityki prorodzinnej powinno być wszędzie tam, gdzie rodzina spotyka się z problemem bezrobocia; winno 
zapewnić z jednej strony odpowiednie warunki, by osoba dotknięta tym problemem mogła utrzymać siebie i rodzinę, z drugiej zaś sprawić, by bez większych trudności, także w wymiarze czasowym, osoba ta znalazła odpowiednią i godną pracę, w której otrzyma godziwe wynagrodzenie. Znane są w Polsce przypadki szkoleń dla osób bezrobotnych, które tak naprawdę były jedynie teoretycznym wspomaganiem tychże ludzi, realnie natomiast nie dawały możliwości znalezienia i podjęcia pracy, co wynikało m.in. z braku stabilizacji rynku pracy. Należy podkreślić, iż państwo nie tworzy rodziny, ale to właśnie ta najmniejsza komórka społeczna domaga się od niego odpowiednich praw ${ }^{22}$, także do pracy.

Państwo powinno również chronić miejsca pracy, także po to, by nie zwiększać poziomu bezrobocia. Po roku 1989 doszło do likwidacji wielu dużych zakładów produkcyjnych, m.in. stoczni, bądź też do skutecznego „wygaszania” znacznej powierzchni zakładów pracy, jak np. Huty im. Tadeusza Sendzimira ${ }^{23}$ w Nowej Hucie. Takie działania skutkują realnym bezrobociem nie tylko wewnątrz samego zakładu pracy, ale także wśród tych, którzy z nim współpracują. Na jednego zwolnionego pracownika danej fabryki przypada około czterech zwolnionych pracowników z nią współpracujących. Są to osoby pracujące w firmach kooperujących, dostarczających np. podzespoły, jak również sklepikarze, kierowcy autobusów itd. Wiele z tych osób ma swoje rodziny, co sprawia, że bezrobocie dotyka nie tylko ich samych, ale również ich najbliższych. Pod koniec maja 2015 roku w urzędach pracy w Polsce zarejestrowanych było aż 93,2 tys. osób zwolnionych z przyczyn leżących po stronie zakładu pracy ${ }^{24}$. Powyższy fakt jest wysoce niepokojący, gdyż blisko 100 tys. osób z przyczyn zależnych jedynie od zakładu pracy straciło możliwość zarobkowania; liczba owa to wielkość średniego miasta w Polsce. Bezrobocie dotyka różnych grup społecznych w Polsce, w tym także inteligencji, jednak o jego przyczynach mało się mówi. Jak stwierdził Jan Paweł II:

W takim stanie mogą się również znajdować pewne kategorie lub grupy pracującej inteligencji, zwłaszcza gdy wraz z coraz szerszym

22 Por. E. Kondziela, Wizja człowieka u podstaw kryzysu rodziny, Wrocław 2011, s. 223.

23 Obecnie ArcelorMittal Poland Oddział w Krakowie.

24 Por. Ministerstwo Rodziny, Pracy i Polityki Społecznej. Departament Rynku Pracy, Bezrobocie rejestrowane w Polsce. Raport miesięczny - maj 2015 r., Warszawa 2015, s. 1. 
dostępem do wykształcenia, z coraz większą liczbą w społeczeństwie ludzi posiadających dyplomy inteligenckie następuje zaniżenie zapotrzebowania na ich pracę. Tego rodzaju bezrobocie inteligencji powstaje lub wzrasta, gdy dostępne wykształcenie nie jest skierowane ku takim rodzajom zatrudnienia czy usługom, jakich wymagają prawdziwe potrzeby społeczeństwa, lub też gdy praca, do której wymagane jest wykształcenie (bodaj zawodowe), bywa mniej poszukiwana i niżej opłacana niż zwykła praca fizyczna. Oczywiście, że wartość wykształcenia sama z siebie stanowi zawsze doniosłe wyposażenie osoby ludzkiej - niemniej pewne procesy „proletaryzacji” są możliwe niezależnie od tego ${ }^{25}$.

Dlatego też po stronie państwa istnieje obowiązek stworzenia odpowiedniego systemu kształcenia wyższego, warunkującego możliwość zdobycia pracy po zakończonych studiach. Fakt ten przekłada się na życie rodzinne, gdyż osoby, które skończyły studia wyższe, najprawdopodobniej będą chciały tego, by ich dzieci również studiowały.

Ważną sprawą dotyczącą polityki prorodzinnej jest również fakt zwrócenia przez państwo uwagi na osoby starsze i chore, dotknięte różnego rodzaju dramatami związanymi ze stanem swojego zdrowia. W tym kontekście państwo ma obowiązek troski o zdrowie każdego obywatela, każdego członka rodziny. I wreszcie pozostaje sprawa pomocy oferowanej przez państwo w momencie, kiedy np. jedno z rodziców umiera. Pomoc ta powinna być realna i charakteryzować się wsparciem zarówno o charakterze materialnym, jak i psychologicznym.

Polityka prorodzinna państwa winna być oparta na szacunku wobec instytucji rodziny. Jan Paweł Il podkreślił:

polityka rodzinna musi być filarem i motorem wszelkiej polityki społecz$n e j$. Dlatego należy podejmować działania społeczne i prawodawcze zdolne zapewnić warunki autentycznej wolności w podejmowaniu decyzji dotyczących ojcostwa i macierzyństwa; konieczne jest też oparcie na nowych zasadach polityki w sferze pracy, rozwoju miast, budownictwa mieszkaniowego i usług, tak aby można było pogodzić 
rytmy pracy z rytmem życia rodzinnego oraz zapewnić rzeczywistą opiekę dzieciom i starcom ${ }^{26}$.

Państwo musi dostrzegać istotną relację, jaka zachodzi pomiędzy jego funkcjonowaniem a życiem poszczególnych członków rodziny oraz rodziny jako wspólnoty. Szacunek wobec rodziny i jej podmiotowe traktowanie ze strony państwa są gwarantem podmiotowego traktowania każdego z obywateli. Osoby odpowiedzialne bezpośrednio za funkcjonowanie państwa, czyli politycy, mają obowiązek podjęcia wszelkich działań na rzecz przyszłości rodziny, tego, by mogła ona się rozwijać, a tym samym - by mogły rozwijać się naród i państwo. Rodzina, zarówno jej starsi, jak i najmłodsi członkowie, powinna zdawać sobie sprawę z tego, że państwo stoi na straży jej istnienia. Świadomość dobrze prowadzonej polityki prorodzinnej sprawia, że ta najmniejsza wspólnota odczuwa bezpieczeństwo w wypełnianiu swoich funkcji przez całe życie jej członków, od ich narodzin do śmierci ${ }^{27}$, czyli przez ten czas, gdy relacje rodzinne istnieją.

Należy jednak podkreślić, iż obok polityki prorodzinnej państwa istotną kwestią dotyczącą życia w rodzinie jest rola kobiety w kontekście jej aktywności o charakterze zawodowym i społecznego statusu, który uległ zmianie.

\section{Zmieniająca się rola kobiet $\mathrm{w}$ obszarze aktywności społeczno-zawodowej}

$\mathrm{Na}$ przestrzeni kolejnych lat zmieniało się życie i funkcjonowanie poszczególnych członków rodziny, w tym także kobiet. Przeobrażenia owe wynikają z kilku przyczyn. Po pierwsze współczesne społeczeństwa, w tym polskie, ulegają ciągłym zmianom o charakterze politycznym, gospodarczym, kulturowym, jak również rodzinnym. O ile w przeszłości model funkcjonowania mężczyzny i kobiety w społeczeństwie oraz rodzinie był przeważnie stały, o tyle obecnie nie jest to już tak oczywiste. Dostrzec można zmiany w funkcjonowaniu i życiu kobiet spowodowane

26 EV 90.

27 Por. EV 92. 
przemianami roku 1989, ale także poszczególnymi decyzjami politycznymi. Na przestrzeni wieków w polskiej kulturze pozycja kobiety jako żony i matki była wysoko ceniona ${ }^{28}$. Kolejnym źródłem zmian są uwarunkowania ekonomiczne. Kobieta współcześnie nie jest już tylko tą, która opiekuje się swoimi dziećmi, ale bardzo często pracuje też zawodowo. Wreszcie można mówić o zmianach o charakterze kulturowym. Podejmowane są próby stawiania na równi mężczyzn oraz kobiet, co jest niemożliwe ze względu na inną płeć i role społeczne. Nie chodzi tutaj o dyskryminację, ale o wskazanie na role, jakie przez wieki odgrywała kobieta i jakie odgrywał mężczyzna. Współczesna kultura, czy właściwie postkultura, pozbawiła kobietę pewnej tajemnicy, tabu i jednocześnie kobiecości. Wydaje się również, iż obecnie szacunek wobec kobiet jest na o wiele niższym poziomie, niż bywało to w przeszłości.

W Liście do kobiet A ciascuna di voi z okazji IV światowej konferencji o kobiecie w Pekinie Ojciec Święty Jan Paweł Il napisał:

Stworzywszy człowieka mężczyzną i niewiastą, Bóg powiedział do obojga: „zaludniajcie ziemię i czyńcie ją sobie poddaną” (por. Rdz 1, 28). Nie tylko dał im moc rodzenia w celu przedłużania w czasie rodzaju ludzkiego, ale równocześnie zadał im tę ziemię, poddając pod ich odpowiedzialne zarządzanie jej bogactwa. Człowiek, istota rozumna i wolna, został posłany, by przeobrażać oblicze ziemi. Za wypełnienie tego zadania, które jest w zasadniczej mierze dziełem kultury, mają od początku jednakową odpowiedzialność zarówno mężczyzna, jak i kobieta. We wspólnocie małżeńskiej i w przekazywaniu życia, we wspólnym zadaniu panowania nad ziemią i czynienia jej sobie poddaną między kobietą i mężczyzną nie ma statycznej i homologicznej równości, lecz nie ma też między nimi zasadniczej różnicy, która prowadziłaby nieuchronnie do konfliktu. Relacją bardziej naturalną, odpowiadającą zamysłowi Bożemu, jest „jedność dwojga” albo „dwoistość”, co pozwala każdemu z nich odczuwać międzyosobowe i wzajemne odniesienie jako dar, który wzbogaca i czyni odpowiedzialnym ${ }^{29}$.

28 Por. L. Dyczewski, Więź między..., dz. cyt., s. 34.

29 AC 8. 
Kobieta tak samo jak mężczyzna jest odpowiedzialna za zmianę rzeczywistości, która ją otacza, za rozwój zarówno społeczny, jak i kulturowy. Owa wspólnotowość z mężczyzną najbardziej widoczna jest w małżeństwie. Przekształcanie ziemi związane jest z pracą zawodową oraz charakteryzuje się aktywnością społeczną. Każdy człowiek posiada prawo do pracy, godziwej płacy i godnego wypoczynku.

Praca nie może być tym, co dominuje nad człowiekiem, powinna mu służyć i go rozwijać. Wszędzie tam, gdzie praca dominuje nad osobą, gdzie człowiek staje się w jakimś sensie przedmiotem pracy, możemy mówić o swoistego rodzaju niewolnictwie. Może to być niewolnictwo jawne, jak w obozach pracy, bądź też ukryte, jak np. ma to miejsce w niektórych krajach współcześnie. Ważne zatem jest, by istniała odpowiednia polityka regulująca prawo pracy i prawa pracownicze. Należy podkreślić, iż państwo polskie po zmianach roku 1989 nie zdołało $^{30} \mathrm{w}$ odpowiedni sposób zapewnić miejsc pracy ${ }^{31}$, także dla kobiet. Jak już wspomniano, bardzo często fakt, iż kobiety pracują, wynika z tego, że są do tego zobligowane sytuacją materialną i koniecznością pomocy w utrzymaniu rodziny. Konstytucja RP stanowi, iż

Każdy ma prawo do bezpiecznych i higienicznych warunków pracy. Sposób realizacji tego prawa oraz obowiązki pracodawcy określa ustawa. Pracownik ma prawo do określonych w ustawie dni wolnych od pracy i corocznych płatnych urlopów; maksymalne normy czasu pracy określa ustawa ${ }^{32}$.

Szczególnie kobieta powinna mieć zapewnione zarówno bezpieczne, jak i higieniczne warunki pracy, co oczywiście dotyczy także mężczyzn. Warto zauważyć, iż to właśnie kobieta winna być chroniona ze względu na macierzyństwo, a zatem musi mieć pewność, iż po urodzeniu dziecka będzie miała zapewnioną możliwość powrotu do miejsca pracy oraz wykonywania swojego zawodu. Znane są przypadki, gdzie pracodawca

30 Do chwili powstawania tej książki.

31 Por. A. Rajkiewicz, Realizacja prawa do pracy jako przedmiot aktywności państwa i niektórych organizacji społecznych, w: Prawo do pracy a polityka społeczna. Materiały $z$ konferencji zorganizowanej przez Katedrę Polityki Społecznej KUL 20 kwietnia 2005 r., red. J. Mazur, Lublin 2005, s. 52.

32 Art. 66 KRP. 
podczas rozmowy kwalifikacyjnej pyta kobietę, czy zamierza zostać matką - jeżeli tak, szansa na otrzymanie pracy maleje. Działania takie są zaprzeczeniem tzw. polityki prorodzinnej, jak również naruszają godność kobiety jako matki i jako osoby. Nie może ona bowiem realizować swojego podstawowego powołania, jakim jest macierzyństwo.

Warto zauważyć, iż chociaż na przestrzeni ostatnich dziesięcioleci kobiety wykonują zawody, które były uważane za typowo męskie, to błędem byłoby twierdzić, iż mogą one wykonywać każdy rodzaj pracy. Wydaje się, że w sektorze związanym z zainteresowaniem osobą ludzką, $\mathrm{z}$ troską o nią, kobiety lepiej się sprawdzają ${ }^{33}$, co wynika z ich wrażliwości i predyspozycji psychicznych. Dzięki temu mogą wypełniać charakterystyczne dla nich zadania. Oczywiście żadna praca kobiety nie może odbywać się kosztem życia rodzinnego, rozmowy z najbliższymi, wychowania dzieci czy też obowiązków domowych. To właśnie rodzina powinna być postawiona przed pracą, choć, jak już wspomniano, w wielu wypadkach jest to niemożliwe. Praca, chociaż w chrześcijaństwie to wartość wysoko ceniona, nie jest najważniejsza. Nie powinna być ostatecznym celem życia człowieka i najważniejszym zadaniem. Cnotą większą od pracowitości jest miłość, dlatego właśnie ta ostatnia wartość winna pracę obejmować, przepełniać, a sama praca powinna służyć miłości. A zatem dostrzeżenie pracy w kontekście miłości może tę pracę uzdrowić i sprawić, że będą usuwane nadużycia, z jakimi można spotkać się w wielu zakładach pracy czy różnego rodzaju firmach ${ }^{34}$. W perspektywie pracy zawsze powinna być widoczna rodzina i jej dobro. Kobieta na pierwszym miejscu winna być żona i matką, a dopiero później tą, która pracuje. Tym samym będzie realizowana zasada pierwszeństwa miłości przed pracą. Każda bowiem praca wpływa na intensywność, jak również rytm czynności wykonywanych przez osobę ludzką ${ }^{35}, w$ tym przez kobietę. Obecnie kobiety coraz więcej czasu spędzają, wykonując pracę zawodową, często kosztem relacji rodzinnych i domowych obowiązków. Spowodowane jest to m.in. chęcią podniesienia standardu życia czy po prostu utrzymania rodziny na podstawowym poziomie. Trudną sytuację mają kobiety samotnie wychowujące

33 Por. R. Kowalczuk, T. Sieczyński, Psychologia i socjologia pracy, Warszawa 1982, s. 268.

34 Por. J. Orzeszyna, Teologiczny i humanistyczny wymiar pracy a zjawisko mobbingu, w: Mobbing w biatych rękawiczkach, red. R. Nęcek, Kraków 2012, s. 63.

35 Por. D. Dobrowolska, Praca w życiu człowieka, Warszawa 1980, s. 190. 
dzieci - znane są przypadki, że pracują w dwóch różnych miejscach, często przekraczając godziny etatu, gdyż pensja, jaką otrzymują za etat, nie wystarcza na utrzymanie rodziny.

Główny Urząd Statystyczny w 2012 roku podał, iż:

Poziom aktywności zawodowej kobiet jest niższy niż mężczyzn. W 2011 r. na 1000 aktywnych zawodowo mężczyzn przypadało 547 biernych zawodowo [...]. Ludność bierna zawodowo jest znacznie sfeminizowana - ponad $60 \%$ tej populacji stanowią kobiety. Współczynnik aktywności zawodowej kobiet wzrósł o 0,8 p. proc. z 47,9\% w 2003 r. do 48,7\% w 2011 r., natomiast dla mężczyzn wskaźnik ten zwiększył się w tym okresie z $62,4 \%$ do $64,7 \%$, tj. o 2,3 punkty proc. Najwyższy odsetek aktywnych zawodowo występuje wśród mężczyzn w wieku 30-39 lat (w 2011 r. na 1000 mężczyzn 943 pracowało lub poszukiwało pracy) oraz wśród kobiet w wieku 35-44 lata (na 1000 kobiet 833 pracowało bądź poszukiwało pracy). Najwyższym poziomem aktywności zawodowej charakteryzują się kobiety z wykształceniem wyższym. Współczynnik aktywności zawodowej dla tej populacji kobiet jest najbardziej zbliżony do wartości analogicznego wskaźnika dla mężczyzn (różnica wynosi ok. 4 punkty proc.) ${ }^{36}$.

Dane powyższe należy odczytywać w kilku aspektach. Przede wszystkim bezrobocia, które w roku 2012 przekraczało 10 proc.; następnie istotny jest fakt, iż część Polaków, w tym kobiet, jest zarejestrowana w urzędzie pracy jako osoby bezrobotne, jednocześnie podejmując pracę „na czarno" za granicą; wreszcie należy pamiętać o kobietach, które wprawdzie nie pracują zawodowo, ale zajmują się wychowywaniem dzieci i prowadzeniem domu, co również jest rodzajem pracy.

Zwrócić uwagę wypada także na inny problem związany z aktywnością zawodową kobiet. Zatrzymać się należy przez chwilę na nielicznej grupie kobiet w Polsce, jaką są kobiety otrzymujące wysokie wynagrodzenie, żyjące jedynie pracą, kosztem założenia rodziny czy też spędzania $\mathrm{z}$ nią czasu. Liczba godzin spędzonych $\mathrm{w}$ pracy nie jest wynikiem konieczności utrzymania rodziny, lecz wypływa z chęci posiadania coraz znaczniejszych dóbr materialnych. Oczywiście pragnienie rozwoju

36 Główny Urząd Statystyczny, Kobiety i mężczyźni na rynku pracy, Warszawa 2014, s. 2-3. 
zawodowego, chęć utrzymania rodziny czy też życia w godnych warunkach nie jest niczym złym, jednak u pewnej części kobiet (mężczyzn też) pojawia się pokusa zarabiania dużej ilości pieniędzy. W rzeczywistości polskiej jest to spowodowane m.in. próbą dorównania, a nawet przekroczenia poziomu zarobków, jakie są na zachodzie Europy. Często odbywa się to, jak już wspomniano, kosztem rodziny, jak również etyki zawodowej.

Warto podkreślić, iż kobiety, pełniąc coraz to nowe funkcje w świecie zawodowym, jednocześnie wykazują dużą kreatywność. Owa kreatywność jest wykorzystywana w pracy zawodowej, bo właśnie w niej winna być ona umocowana ${ }^{37}$ - poprzez kreatywność kobieta realizuje siebie, jak również może ubogacać otaczającą rzeczywistość. Chodzi tutaj o ubogacenie pełne, mające na celu troskę o dobro innych ludzi.

Główny Urząd Statystyczny podaje, iż mężczyźni dominują na stanowiskach kierowniczych. W 2011 roku kobiety na wspomnianych miejscach pracy stanowily 40 proc. ${ }^{38}$ Dane te wskazują na pewien utrzymujący się model społeczny, gdzie funkcje kierownicze w większości należą do mężczyzn. Nie można jednak wprowadzać schematu, który będzie mówił o tym, iż pełnienie funkcji kierowniczych powinno być tak samo przypisane kobietom jak i mężczyznom. Schemat taki byłby sztuczny i jednocześnie narzucałby z góry pewien rodzaj zachowań w miejscach pracy. Należy też podkreślić, iż różnica pomiędzy liczbą mężczyzn sprawujących stanowiska kierownicze a odpowiadającą temu liczbą kobiet wynosi zaledwie 10 proc.

Obok pracy zawodowej wydaje się, iż w ostatnich latach zmienia się także aktywność społeczna kobiet. Tak oto kobiety wychodzą za mąż, mając średnio 28 lat $^{39}$. Wiele z nich zmienia również swoje miejsce zamieszkania w momencie osiągnięcia dorosłości. Widoczne jest to szczególnie w dużych ośrodkach, w których młodzi ludzie po studiach chcą znaleźć pracę. Późniejsze niż jeszcze kilkanaście lat temu pobieranie się spowodowane jest m.in. podejmowaniem studiów wyższych przez większą niż wcześniej liczbę absolwentów szkół średnich. W Polsce w 2015 roku około 80 proc. tychże absolwentów studiowało.

37 Por. R. J. Neuhaus, Biznes i Ewangelia. Wyzwanie dla chrześcijanina-kapitalisty, tłum.

B. Szlachta, Poznań 1993, s. 192.

38 Por. Główny Urząd Statystyczny, Kobiety i mężczyźni..., dz. cyt., s. 4.

39 Por. T. Borutka, J. Wal, Zarys socjologii..., dz. cyt., s. 109. 
Kolejną kwestią związaną z późniejszym założeniem rodziny jest sprawa znalezienia pracy i możliwości utrzymania zarówno siebie, jak i rodziny. Wszystko to sprawia, że aktywność społeczna i zawodowa kobiet uległa i nadal ulega zmianie.

Nie sposób nie wspomnieć o zaangażowaniu społecznym kobiet - są one nie tylko członkami partii politycznych, ale także odgrywają w nich istotne role, co w czasach komunizmu należało do rzadkości. Kobiety działają również na polu pomocy innym, zajmując się działalnością charytatywną, wspomagają swoim czasem i środkami finansowymi wiele różnych organizacji, są coraz bardziej widoczne w życiu społecznym, a tym samym - publicznym. Angażują się w ruchy, u których źródeł leży działanie Kościoła katolickiego, są wolontariuszkami pomagającymi osobom dotkniętym wojną, jak chociażby na Ukrainie. Zmienia się również rola kobiety $\mathrm{w}$ życiu rodzinnym. O ile jeszcze nie tak dawno, szczególnie w mniejszych, bardziej skomunizowanych środowiskach, model rodziny wyglądał $w$ ten sposób, iż to kobieta w większości przypadków wychodziła z dziećmi na spacer czy pchała wózek, o tyle dzisiaj te zadania coraz częściej wykonują mężczyźni.

Życie zawodowe, jak również społeczne kobiet powinno być ściśle związane z rodzinnym. Rodzina bowiem jest szkołą cnót społecznych ${ }^{40}$. Dlatego życie społeczne i zawodowe kobiet z jednej strony winno być tymi cnotami przeniknięte, a $\mathrm{z}$ drugiej - to właśnie kobieta powinna owych cnót uczyć swoich najbliższych, szczególnie dzieci, co stanowi jedną z metod otwarcia na wspólnotę, bez której osoba ludzka nie może się w pełni rozwijać ${ }^{11}$. Kobieta bowiem jest w stanie przekazywać wartość cnót społecznych nie tylko w sposób czysto teoretyczny, ale także, lepiej powiedzieć, przede wszystkim w sposób praktyczny. Zarówno dziecko, jak i inni członkowie rodziny, widząc, w jaki sposób postępuje matka, żona, babcia w życiu zawodowym i społecznym, mogą czerpać z jej postępowania wzór. Na przestrzeni ostatnich lat i dziesięcioleci żyło w Polsce wiele kobiet, które łączyły swoje życie rodzinne, społeczne i zawodowe, jednocześnie zachowując cnoty społeczne ${ }^{42}$. Przykładem jest postać Anny Walentynowicz, współtwórczyni „Solidarności”, osoby,

40 Por. J. Buxakowski, Wprowadzenie do teologii duszpasterstwa rodzin, Pelplin 1999, s. 122.

41 Por. E. Kondziela, Wizja człowieka..., dz. cyt., s. 149.

42 Por. S. Cenckiewicz, Anna Solidarność. Życie i działalność Anny Walentynowicz na tle epoki (1929-2010), Poznań 2010, s. 77. 
która do końca życia działała na rzecz Polski, najpierw walcząc o jej wolność, a następnie o pamięć historyczną, jednocześnie łącząc tę działalność z życiem rodzinnym i religijnym. Klamrą spinającą jej życie są dwie daty i dwa miejsca związane z historią Polski. To dzień narodzin, 15 sierpnia 1929 roku w Równem na Kresach na Wołyniu ${ }^{43}$, dokładnie dziewięć lat po zwycięstwie Polaków nad bolszewikami, oraz dzień śmierci - zginęła 10 kwietnia 2010 roku pod Smoleńskiem, udając się wraz z prezydentem RP na uroczystości upamiętniające 70 . rocznicę mordu katyńskiego. Kobiet, które w czasach komunizmu walczyły o wolność Polski, które mimo propozycji awansu zawodowego, jak również społecznego pozostały niezależne od władzy komunistycznej i nie podjęły z nią współpracy, było wiele. Są one do dzisiaj cichymi, często nieznanymi z imienia i nazwiska bohaterkami, dla których honor i cnoty społeczne były i wciąż pozostaną najważniejszym punktem odniesienia.

Wydaje się, że postawa tych kobiet powinna być wzorem dla żyjących w ciągłych zmianach społecznych kobiet polskich pierwszej połowy XXI wieku. Istotne jest to, iż w czasach komunizmu w porównaniu z innymi krajami Europy Zachodniej zaangażowanie społeczne Polaków, w tym także kobiet, było niewielkie. Podobną sytuację dostrzegamy również dzisiaj. Jednak spośród ogółu Polaków obecnie bardziej zaangażowane społecznie są kobiety.

Zaangażowanie społeczne kobiet, zarówno w mniejszych, jak i większych ośrodkach, przybiera różne formy - często wydaje się, że mało spektakularne, jednak w rzeczywistości istotne i związane z pracą zawodową. Tak oto istnieją szkoły, które organizują w ramach wolnego czasu nauczycieli np. Dzień Dziecka, zapraszając nie tylko swoich uczniów, ale także ich rodziców. Działanie takie ma zarówno charakter zawodowy, jak i społeczny oraz jest wykonywane głównie przez kobiety, gdyż to one stanowią większość liczebną w zawodzie nauczyciela w Polsce. Stąd też mówi się o zawodach sfeminizowanych, do których zaliczyć można właśnie zawód nauczyciela. Aktywność kobiet na polu społecznym widoczna jest także w podejmowaniu innych działań, jak chociażby w kwestiach związanych z wyjazdami w ramach organizacji Lekarze bez Granic i pomocą osobom dotkniętym m.in. konfliktami zbrojnymi.

43 Por. S. Cenckiewicz, Anna..., dz. cyt., s. 34. 
Nie zawsze jednak można mówić o wyjeździe zarówno kobiet, jak i mężczyzn w celu pomocy potrzebującym. Od kilkunastu lat dostrzega się w Polsce nasilanie się zjawiska zwanego emigracją zarobkową, która powoduje eurosieroctwo, chociaż sam problem nie jest rzeczywistością nową.

\section{Zjawisko eurosieroctwa w kontekście realizacji celów wychowawczych rodziny}

Emigracja zarobkowa w Polsce posiada stosunkowo długą historię, lecz jej szczególny wymiar widoczny jest w pierwszej dekadzie XXI wieku. Polacy podejmowali emigrację za chlebem jeszcze przed I wojną światową, potem w czasach PRL-u, choć wtedy wiązała się ona również z emigracją z racji politycznych, wreszcie po zmianach ustrojowych roku 1989, co było skutkiem powojennego oddziaływania obcego państwa w Polsce ${ }^{44}$. Szczególnie dużo Polaków wyjechało za pracą po przystąpieniu Polski do Unii Europejskiej w 2004 roku. Głównymi kierunkami tej emigracji są Austria, Niemcy, Wielka Brytania, ale też i Norwegia. Przykładem niech będzie wspomniana Austria - według danych polskiego Ministerstwa Spraw Zagranicznych z 2012 roku w kraju tym mieszkało około 80 tys. Polaków, z czego większość w Wiedniu. Z kolei około 20 tys. posiadało obywatelstwo austriackie ${ }^{45}$. Austriackie Ministerstwo Spraw Wewnętrznych podaje, że w Austrii na dzień 31 grudnia 2012 roku było zameldowanych 58,090 tys. obywateli polskich (w Wiedniu 38,761 tys.), spośród nich 23,952 tys. było zatrudnionych ${ }^{46}$. W wymienionych państwach Polacy i inni emigranci zarobkowi stanowią tanią siłę roboczą. Jednocześnie Polacy cenieni są za obowiązkowość i dobrze wykonywaną pracę. Polskich emigrantów można podzielić na dwie zasadnicze grupy. Otóż pierwszą grupę osób stanowią ci, którzy wyjeżdżają i osiedlają się na stałe poza granicami Polski, drugą zaś osoby pracujące wprawdzie za granicą, ale budujące domy w Polsce, kupujące tutaj mieszkania i wiążące swoją przyszłość z krajem ojczystym. Państwo polskie nie

44 Por. S. Borkacki, Polska w wielkiej potrzebie, Krzeszowice 2001, s. 52.

45 Por. Ministerstwo Spraw Zagranicznych, Raport o sytuacji Polonii i Polaków za granica 2012, Warszawa 2013, s. 22.

46 Por. Ministerstwo Spraw Zagranicznych, Raport o sytuacji Polonii..., dz. cyt., s. 22. 
było w stanie powstrzymać tych ludzi przed wyjazdem za granicę poprzez zapewnienie godnych warunków pracy oraz płacy po wstąpieniu w struktury Unii Europejskiej. Ci, którzy wyjeżdżają, chwalą sobie nie tylko odpowiednie stawki, jakie otrzymują za godzinę pracy, ale również (choć nie zawsze) lepsze jej warunki, w tym m.in. atmosferę. Należy jednak podkreślić, iż osób tych brakuje w Polsce, gdzie widoczna jest zapaść pokoleniowa, a Polacy stają się społeczeństwem coraz szybciej się starzejącym i wymierającym ${ }^{47}$.

Co więcej - niejednokrotnie wyjeżdżają osoby dobrze wykształcone, służące swoimi umiejętnościami na zachodzie Europy (to rzadsze przypadki) bądź też pracujące na stanowiskach czy w zawodach nieodpowiadających ich wykształceniu. Często podkreślają, iż gdyby w ojczystym kraju ich pensje były na odpowiednim poziomie, wówczas by w nim pozostali. Jak odnotowuje Główny Urząd Statystyczny:

Szacuje się, że w końcu 2013 roku poza granicami Polski przebywało czasowo około 2196 tys. mieszkańców naszego kraju, tj. o 66 tys. (3,1\%) więcej niż w 2012 roku (około 2130 tys.). W Europie w 2013 r. przebywało około 1891 tys. osób (w 2012 roku - około 1816 tys.), przy czym zdecydowana większość - około 1789 tys. - emigrantów z Polski przebywała w krajach członkowskich UE. Liczba ta zwiększyła się o 69 tys. w stosunku do 2012 roku. Wśród krajów należących do UE nadal najwięcej osób przebywało w Wielkiej Brytanii (642 tys.), Niemczech (560 tys.), Irlandii (115 tys.) oraz w Holandii (103 tys.) i we Włoszech (96 tys.). [...] Szacuje się, że ponad 75\% czasowych emigrantów z Polski przebywa zagranicą co najmniej 12 miesięcy. Osoby te zaliczane są do emigrantów długookresowych i - razem z osobami, które wyemigrowały na stałe - powinny być uwzględnione w stanach ludności poszczególnych krajów (są rezydentami krajów przyjmujących). Zdecydowana większość polskich emigrantów przebywa zagranicą w związku z pracą, chociaż wraz z upływem czasu zwiększa się też odsetek osób - członków rodzin polskich emigrantów, pozostających na ich utrzymaniu (małżonkowie, dzieci). Polacy, którzy wyjechali do innych krajów w okresie od maja 2004 r.

47 Stan na pierwszą połowę 2015. 
do końca 2013 r. na pobyt czasowy powyżej 3 miesięcy, w zdecydowanej większości wyjechali w celu podjęcia tam pracy ${ }^{48}$.

Widać z powyższych statystyk, że realnie w Polsce mieszka nie około $38 \mathrm{mln}$, ale około $36 \mathrm{mln}$ osób. Nadal najbardziej popularnym kierunkiem emigracji jest Wielka Brytania, co ma swoje uwarunkowania w pierwszych falach emigracji do tego kraju w latach 90. ubiegłego wieku, a przede wszystkim w pierwszej dekadzie XXI wieku. Spowodowane one były wysokim przelicznikiem funta w stosunku do złotego. Jeszcze kilka lat temu za 1 funta w Polsce płacono około 7 złotych. Z kolei Niemcy z państw tzw. starej Unii Europejskiej położone są najbliżej Polski - choć emigranci zarobkowi kierują się często w strony dawnej RFN, znane są jednak przypadki, że kupują oni mieszkania na terenach nieistniejącej już NRD. Ważnym kierunkiem emigracji jest położona niedaleko Polski Austria, szczególnie jej stolica - Wiedeń, o czym już wyżej wspomniano. Kierunek ten jest spowodowany m.in. bliskim położeniem tego kraju i jego najważniejszego miasta w stosunku do południowych części Rzeczypospolitej. Z niektórych rejonów Polski południowej można szybciej dojechać samochodem do Wiednia niż do Warszawy. Znane są też dalsze kierunki emigracji zarobkowej, jak Włochy, Stany Zjednoczone czy wreszcie Kanada. Tak oto:

Posługując się danymi z sondażu American Community Survey z 2012 r., w którym badani mogą zadeklarować polskie pochodzenie, w USA obecnie mieszka 9.659.207 osób polskiego pochodzenia ${ }^{49}$.

Emigracja jest związana z różnym traktowaniem przez kraj przyjmujący tych, którzy podejmują decyzję o pracy poza granicami własnej ojczyzny. Istotna jest godność emigrantów, zarówno dotycząca warunków, w jakich wykonują pracę w kraju przyjmującym, warunków zapłaty za tę pracę, jak i warunków mieszkaniowych i bytowych. Należy jednak podkreślić, iż emigranci, w tym ci z Polski, wykonują na Zachodzie często te prace, których osoby z tamtych krajów wykonywać nie chcą.

48 Główny Urząd Statystyczny, Informacja o rozmiarach i kierunkach czasowej emigracji $z$ Polski w latach 2003-2013, Warszawa 2014, s. 3-4.

49 Ministerstwo Spraw Zagranicznych, Raport o sytuacji Polonii..., dz. cyt., s. 216. 
Jest to niejednokrotnie praca niezgodna $\mathrm{z}$ ich wykształceniem, umiejętnościami, jak również możliwościami, a przecież praca stanowi dobro człowieka ${ }^{50}$ i powinna mu służyć.

Emigracja nie wpływa pozytywnie na relacje rodzinne i utrzymywanie więzi wewnątrz tej najmniejszej komórki społecznej. Ludzie wyjeżdżający za chlebem zostawiają często w kraju pochodzenia rodziców, dalszych krewnych, a także dzieci. Emigracja zarobkowa dotyka niemal każdej części Polski, wyjeżdżają osoby zarówno ze wsi, małych miast, jak również takich ośrodków jak np. Kraków. Emigracja zarobkowa w kontekście rodziny, mimo iż zapewnia jej utrzymanie, jak również w miarę godne warunki bytu, zawsze jest większą lub mniejszą „wyrwą” w tkance życia rodzinnego. Nawet wiele lat po powrocie emigrantów zarobkowych do kraju relacje rodzinne mogą nie ulec poprawie. W szczególny sposób dotyka to dzieci. Znane są przypadki, że nie tylko jedno z rodziców, ale nawet oboje pracują za granicą. W pierwszym wypadku dziecko (bądź dzieci) wychowywane jest przez rodzica pozostałego w kraju, a tym samym pozbawione zostaje codziennego ciepła i opieki bądź matki, bądź też ojca; w drugim przypadku natomiast wychowuje się praktycznie przy ograniczonym wpływie rodziców.

Na zlecenie rzecznika praw dziecka zostały przeprowadzone badania dotyczące eurosieroctwa. Badania te przeprowadzono na grupie zaledwie 100 szkó $^{51}$. To wskaźnik niewielki, tym bardziej że w jednym dużym mieście jest kilkadziesiąt szkół. Istnieje obecnie niestanowiąca dużych problemów możliwość sprawdzenia, ile osób jest objętych eurosieroctwem, zarówno jeśli chodzi o uczniów szkół podstawowych, jak i liceów. We wszystkich tych szkołach informacje na temat miejsca przybywania rodziców posiadają przede wszystkim wychowawcy klas, ale w przypadku zjawiska eurosieroctwa często także pedagodzy szkolni. Przyjrzeć można się jednak wspomnianym badaniom przeprowadzonym dla rzecznika praw dziecka, gdyż w jakimś zakresie, bardzo jednak niepełnym, rzucają światło na fakt eurosieroctwa:

50 Por. LE 9.

51 Por. B. Walczak, Ogólnopolskie badanie „Dziecko, rodzina i szkoła, wobec migracji rodzicielskich: 10 lat po akcesji do Unii Europejskiej”. Realizowane na zlecenie Rzecznika Praw Dziecka przez Pedagogium WSNS, Warszawa 2014, s. 91. 
Rozłąki z przynajmniej jednym z rodziców w ciągu trzech lat poprzedzających badanie doświadczyła jedna piąta uczniów. Oznacza to siedmiopunktowy spadek w porównaniu z wynikami z 2008 roku, co może wynikać ze zmiany skali odpływu, ale też częstszego podejmowania migracji osiedleńczych. Warto jednocześnie zauważyć, że migracja zarobkowa w rodzinach $\mathrm{z}$ dziećmi w wieku szkolnym jest częstsza niż w odniesieniu do całej populacji; rodzice reprezentują grupę wiekową charakteryzującą się podwyższoną skłonnością do mobilności przestrzennej. Siedem na dziesięć migracji rodzicielskich to wyjazd samego ojca opiekuna, $14,8 \%$ migracja matki, $17,2 \%$ to migracja obydwojga, $\mathrm{w}^{2} / 3$ przypadków o charakterze naprzemiennym. Najczęściej wybieraną strategią są wyjazdy krótkotrwałe (do dwóch miesięcy), na rozłąkę przekraczającą jeden rok kalendarzowy zdecydowało się 11,7\% spośród migrujących matek i 19,7\% ojców. Takiej długotrwałej rozłąki doświadczyło 3,2\% ogółu uczniów ${ }^{52}$.

Jak wspomniano wyżej, badania przeprowadzone dla ówczesnego rzecznika praw dziecka Marka Michalaka są wysoce niepełne, gdyż nie obejmują wszystkich szkół w Polsce i wszystkich uczniów. Skala emigracji rodziców dzieci w wieku szkolnym jest jednak niezwykle wysoka, niepokojący również jest fakt, iż w latach, w których zostały dokonane badania, zwiększyła się liczba emigrantów zarobkowych mających dzieci, a zatem zwiększa się również realnie zjawisko eurosieroctwa. Częściej wyjeżdżają ojcowie, co skutkuje brakiem poczucia „ręki ojca” w wychowaniu, a co za tym idzie - wskaźnik braku męskiego wychowania jest wyższy niż brak wychowania przez matkę oraz występuje brak tak istotnego przykładu ${ }^{53}$. Warto zauważyć, że na przykładzie tej niewielkiej grupy badanych osób widoczna jest wysoka emigracja obojga rodziców, sięgająca blisko 20 proc. Zatem coraz częściej mamy do czynienia ze zjawiskiem już nie częściowego (gdzie wyjeżdża jedno z rodziców), ale całkowitego eurosieroctwa.

Brak któregokolwiek z rodziców spowodowany emigracją zarobkową niewątpliwie ma wpływ na kształtowanie i wychowanie młodego człowieka, który nie ma codziennego wzorca i codziennej opieki bądź matki,

52 B. Walczak, Ogólnopolskie badanie..., dz. cyt., s. 91.

53 Por. EV 92. 
bądź też ojca, a tym samym jest mocniej zagrożony negatywnymi wzorcami zachowania płynącymi z mediów ${ }^{54}$. Znane są także przypadki, gdy oboje rodzice pracują poza granicami Polski, a dzieci są wychowywane np. przez dziadków. W tym wypadku różnica pokoleniowa jest tak duża, że dzieci mogą dziadkami manipulować w celu osiągnięcia korzyści dla siebie, co z kolei nie wpływa pozytywnie na wychowanie. Co więcej są to dzieci, które często zarówno ubiorem, jak i posiadanymi rzeczami materialnymi, jak np. telefonami komórkowymi najnowszej generacji, odróżniają się od swoich rówieśników, których rodzice pracują w Polsce. To z kolei powoduje nie tylko niezdrową konkurencję wewnątrz klasy czy szkoły, ale także sprawia, że niektóre dzieci noszą w sobie poczucie wyższości ze względu na posiadane dobra materialne, poczucie, które jest zewnętrzną otoczką przykrywającą świadomość sieroctwa niespowodowanego śmiercią rodzica bądź rodziców. Takie zachowanie szczególnie jest widoczne wśród nastolatków - a często jeszcze mentalnych dzieci - którzy nie potrafią odróżnić zachowania właściwego od tego niegodnego. Emigracja zarobkowa niesie ze sobą brak rodzicielstwa na co dzień, a zatem również brak odpowiedniego wychowania, co więcej dziecko z rodziny, w której rodzice wyjeżdżają w poszukiwaniu pracy, sądzi podświadomie, iż życie rodzinne powinno być podporządkowane życiu ekonomicznemu, a kontakty osób najbliższych - pracy zarobkowej poza granicami kraju.

W wychowaniu istotny jest przykład, jaki rodzice winni dawać dzieciom. W przypadku eurosieroctwa takiego przykładu dzieci nie mają na co dzień, w związku z tym trudno mówić tutaj o bezpośrednim, a tym samym pełnym wychowaniu ze strony rodziców. A przecież

Prawo-obowiązek rodziców do wychowywania jest czymś istotnym i jako taki związany jest z samym przekazywaniem życia ludzkiego; jest on pierwotny i mający pierwszeństwo w stosunku do zadań wychowawczych innych osób, z racji wyjątkowości stosunku miłości łączącej rodziców i dzieci; wyklucza zastępstwo i jest niezbywalny, dlatego nie może być całkowicie przekazany innym ani przez innych zawłaszczony. Nie można zapominać, że poza tymi cechami, charakteryzującymi zadanie wychowawcze rodziców, najgłębszym

54 Por. S. Borkacki, Polska..., dz. cyt., s. 16. 
i określającym je elementem jest miłość ojcowska i macierzyńska, która znajduje w dziele wychowawczym wypełnienie doskonałej służby życiu: miłość rodzicielska od początku staje się duszą, a przez to i normą, która inspiruje i nadaje kierunek całej konkretnej działalności wychowawczej, ubogacając ją tak cennymi owocami miłości, jak czułość, stałość, dobroć, usłużność, bezinteresowność i duch ofiary ${ }^{55}$.

Wszędzie tam, gdzie obowiązki wychowania są przekazywane innym osobom z powodu emigracji zarobkowej, czy to tylko jednemu z rodziców, czy to komuś innemu z rodziny, wspomnianym dziadkom, wujkom itd., dochodzi do braku pełnego wychowania, ponieważ aby miłość rodzicielska mogła objawiać się w wychowaniu dzieci, potrzebna jest obecność rodziców. Telefon, Internet, takie komunikatory jak Skype czy Facebook nie zapewnią czułości, dobroci, ducha ofiary, usłużności i wychowania. Mogą być one pomocą w kontaktach między dziećmi i rodzicami, nigdy jednak kontaktów owych nie zastąpią.

W całym, jakże trudnym procesie wychowania najważniejszą rolę obok wychowywanego odgrywa wychowawca, ponieważ nie wychowują same idee, ale osoba ludzka ${ }^{56}$. Można bowiem młodemu człowiekowi przekazywać idee i wzorce zachowania jedynie w sposób teoretyczny, ale skutek tego będzie minimalny.

Wychowanie, jak wiadomo, polega na kształtowaniu jednostki, podmiotu, konkretnego człowieka, będącego w konkretnym wieku, na konkretnym etapie swego życia, mającego bardzo konkretne problemy. Dziecko, które nie może być wysłuchane bezpośrednio przez swoich rodziców, nie jest w stanie opowiedzieć im o swoich radościach i problemach, szuka rozwiązania w tych wymiarach życia, które nie służą odpowiedniemu wychowaniu. Współcześnie są to narkotyki, seks, alkohol, środowisko mogące deprawować młodego człowieka.

Dzieci emigrantów zarobkowych odczuwają m.in. pustkę oraz obcość rodzica. Przykładów jest wiele i pojawiają się od najmłodszych lat: chłopiec trzyipółletni oddany pod opiekę dziadkom po wyjeździe rodziców do pracy za granicę w przedszkolu permanentnie płakał. $\mathrm{Na}$

55 FC 36.

56 Por. A. Solak, Wychowanie chrześcijańskie i praca ludzka. Studium współzależności, Warszawa 2004, s. 89. 
pytanie wychowawczyni, jaki jest powód płaczu, odpowiedział, że wyjazd rodziców, i obiecał, iż przestanie płakać, gdy rodzice wrócą ${ }^{57}$. Dziecko niespełna czteroletnie, odczuwając osamotnienie spowodowane brakiem rodziców, reaguje tak, jak potrafi wobec tego faktu, czyli płaczem. Kolejny przykład to dramat czternastoletniego chłopaka. Po wyjeździe jego matki oraz ojczyma do Wielkiej Brytanii w celach zarobkowych młodzieniec został oddany pod opiekę dziadków wraz z trójką młodszego rodzeństwa. Rodzice byli przekonani, że chłopak, jako najstarszy, lubiący się uczyć, w tym języka angielskiego, najlepiej będzie w stanie poradzić sobie w tej sytuacji. Młodzieniec napisał w języku angielskim list do rodziców i popełnił samobójstwo. Stało się to kilka miesięcy po ich wyjeździe do Angliii ${ }^{58}$. W drugim z opisanych przypadków mamy do czynienia już nie z płaczem, chociaż dla trzyipółletniego chłopca trauma spowodowana pracą rodziców poza granicami kraju pozostanie także w okresie dorastania, lecz z decyzją o odebraniu sobie życia. Obie sytuacje, choć są różnymi reakcjami, odnoszą się do tego samego źródła, czyli pustki, a więc świadomości w jakimś sensie straty rodziców i chęci poradzenia sobie z tym problemem. Nic i nikt nie wypełni owej pust$\mathrm{ki}$, ani dziadkowie, ani rodzeństwo, a tym bardziej instytucje takie jak szkoła, czy też osoby z grupy rówieśniczej lub innych grup.

Młody człowiek, ale także dziecko, potrzebuje wypełnienia tejże pustki w wymiarze obecności rodziców oraz w wymiarze podejmowania przez nich trudu wychowania. Ich obecność, stawiane przez nich wymagania, ukazywanie świata wartości, dawanie przykładu z jednej strony bywa niekiedy przyczyną buntu dziecka, ale z drugiej - odczytuje ono, że jest to troska rodziców, i ma świadomość, że jest kimś ważnym dla nich, a jeżeli dla nich, to także dla innych osób.

Widać zatem, że zmiany ustrojowe w Polsce zapoczątkowane w 1989 roku nie przyniosły odpowiednich dla rodziny, pozytywnych skutków. Spowodowały bowiem zranienia psychiki, co jest dostrzegalne w wymiarze konfliktu i kryzysu między generacjami ${ }^{59}$. Sytuacja taka uwidacznia

57 Por. J. M. Młyński, W. Szewczyk, Rodzina wobec dylematów migracji zarobkowej. Badania i analizy, Warszawa 2012, s. 118.

58 Por. J. M. Młyński, W. Szewczyk, Rodzina wobec dylematów..., dz.cyt., s. 127.

59 Por. S. Wierzchosławski, Rodzina w okresie transformacji demograficznej i społeczno-ekonomicznej, w: Rodzina w zmieniajacym się społeczeństwie, red. P. Kryczka, Lublin 1997, s. 80. 
się także w wymiarze obcości, jaką dziecko może odczuwać wobec rodzica pracującego poza granicami kraju. Za przykład niech posłuży sprawa czteroosobowej rodziny, której ojciec wyjechał do Niemiec, by móc więcej zarabiać. Początkowo synowie w wieku 15 oraz 10 lat tęsknili za ojcem, jednak z czasem zaczął im odpowiadać następujący schemat: przyjazdy do ojca do Niemiec na tydzień lub dwa i jego spędzanie czasu z rodziną w Polsce podczas krótkich urlopów ${ }^{60}$. Pomimo wcześniejszej tęsknoty, jaka zrodziła się u braci, z czasem nie tylko przyzwyczaili się, ale i zaczął im odpowiadać model ojca, którego nie ma na co dzień w domu. Rodzic staje się kimś obcym, momentami nawet zbytecznym, co wynika m.in. z tego, iż dzieci zdają sobie sprawę, że jeżeli jedno z rodziców bądź dwoje wybiera pracę za granicą po to, by móc więcej zarobić, to wystarczą przesyłane do kraju środki finansowe, natomiast sama obecność może być swoistego rodzaju ciężarem. To oczywiście sprawia, że funkcja wychowawcza takiego rodzica oparta na autorytecie praktycznie przestaje istnieć. Rodzic zostaje sprowadzony jedynie do roli dostarczyciela środków finansowych pozwalających na lepsze od rówieśników ubranie się czy posiadanie lepszego laptopa. Relacje wychowawczo-osobowe zostają przeniesione na relacje przedmiotowo-materialne.

Owa nieobecność wychowawcza rodziców sprawia często, że pojawia się dystans między nimi a dzieckiem, a w ostateczności skutkuje to osłabieniem kontaktu, dalej trudnościami, jakie pojawiają się w porozumieniu pomiędzy tymi dwiema stronami ${ }^{61}$. Wychowanie, jak wyżej napisano, to szereg czynników - jednym z nich jest autorytet, jaki powinno każde z rodziców zbudować u swojego dziecka. Autorytet jest związany z poczuciem bezpieczeństwa, pewności i trwałości relacji między dzieckiem a rodzicem. Brak takiego poczucia, jak również brak dostrzeżenia autorytetu w rodzicu mogą prowadzić do najbardziej drastycznych form, o jakich wspomniano wyżej, czyli nawet do popełnienia samobójstwa. W porównaniu z latami 90 . ubiegłego wieku wskaźnik samobójstw wśród dzieci do 14 roku życia uległ dwukrotnemu zwiększeniu, natomiast wśród osób do 19 roku życia spotykamy podwyższenie liczby samobójstw o 100 proc. W roku 2006 spośród 5928 zamachów

60 Por. J. M. Młyński, W. Szewczyk, Rodzina wobec dylematów..., dz. cyt., s. 126.

61 Por. T. E. Olearczyk, Sieroctwo i osamotnienie. Pedagogiczne problemy kryzysu wspótczesnej rodziny, Kraków 2007, s. 193. 
samobójczych aż 5100 skończyło się śmiercią, a spośród tej ostatniej liczby 304 samobójstwa zakończone śmiercią miały miejsce wśród młodzieży do 19 roku życia, w tym aż 57 przypadków dotyczyło osób, które nie ukończyły 14 roku życia ${ }^{62}$. Liczba samobójstw wśród dzieci i młodzieży wskazuje na fakt niemożności poradzenia sobie przez te dwie grupy z trudnościami, z jakimi spotykają się u progu dorosłości. W przypadku eurosieroctwa młodzi ludzie mają niejednokrotnie (choć nie zawsze) zapewnione warunki bytowania, jednak nie potrafią odnaleźć się w sytuacji osamotnienia wychowawczego.

A zatem można na podstawie powyższych faktów dokonać następującego podziału międzypokoleniowego: osoby urodzone przed II wojną światową, w czasie jej trwania i krótko po niej, były wychowywane w znacznej mierze przez pokolenie przedwojenne, pamiętające wolną Polskę, w której życie oparte było na jasnych zasadach moralnych i wychowawczych; następnie istnieje pokolenie urodzone w latach 50. i 60., wychowywane na podstawie dwóch różnych systemów wartości - albo tego związanego z II RP, a zatem z prawdą, sprawiedliwością, moralnością, albo tego propagującego utopijną i nieludzką ideologię marksistowską, głoszącą antywartości i widzącą w życiu człowieka szansę tam, gdzie możliwy jest kompromis moralny. Potem można mówić o pokoleniu końca lat 70. oraz pierwszej połowy lat 80., pamiętającym PRL i w nim wychowywanym, często wbrew oficjalnej ideologii, ale zdobywającym wykształcenie średnie czy wyższe już w IIl RP. Wreszcie istnieje pokolenie niepamiętające PRL-u, wchodzące obecnie na rynek pracy lub już od kilku lat uczestniczące w nim. Jednak wszystkie te pokolenia, choć w najmniejszym stopniu to ostatnie, łączy jedna kwestia: pomimo różnych, nieraz trudnych warunków, czy to wojennych, czy to powojennych, wbrew dwóm systemom totalitarnym, jakie dotknęły Polskę: niemieckiemu nazizmowi oraz sowieckiemu komunizmowi, były one wychowywane przez swoich rodziców. Sieroctwo natomiast było kojarzone ze śmiercią jednego lub dwojga z tychże rodziców. Obecnie spotykamy pokolenie, które - mimo iż rodzice żyją - jest w pewnej części pokoleniem sierot, skazanych na obserwację zdobywania środków finansowych przez rodziców, bądź jednego z nich, poza granicami kraju. Jakaś część tego pokolenia została pozbawiona wartości, która istniała

62 Por. T. E. Olearczyk, Sieroctwo..., dz. cyt., s. 199. 
nieprzerwanie przez wieki, wartości wychowania, a więc kształtowania osobowości, postaw itd. Jednak obok eurosieroctwa coraz większym problemem staje się rosnąca liczba rozwodów w Polsce.

\section{Zwiększająca się liczba rozwodów i ich wpływ na zmieniające się pojęcie rodziny}

Jedną z wartości życia rodzinnego i małżeńskiego, o której już wspomniano, jest integralność oraz trwałość instytucji małżeńskiej ${ }^{63}$. Wydaje się, iż szczególnie po Il wojnie światowej doszło do zwiększającej się liczby rozwodów, zwłaszcza w krajach Europy Zachodniej. W Polsce pomimo komunistycznej propagandy i realnej walki z wartościami rodzinnymi odsetek małżeństw, które ulegały rozpadowi, nie był tak duży, jak na Zachodzie. Przełom nastąpił po 1989 roku. Należy podkreślić, iż mówiąc o rozwodach w Polsce i ich zwiększającej się liczbie, nie powinno się ujmować tej kwestii jedynie w perspektywie ogólnopolskiej. Należy bowiem dostrzegać pewne zasadnicze różnice, jakie występują w poszczególnych obszarach naszego kraju, właśnie w kontekście rozwodów. Warto zatem odpowiedzieć na pytanie, skąd te różnice. Otóż przyczyn jest kilka, przede wszystkim tych o charakterze historycznym, ale także tych leżących po stronie braku odpowiedzialności za rodzinę ${ }^{64}$. Historia bowiem mimo faktów dokonanych nie jest bytem zamkniętym, lecz w większym lub mniejszym stopniu wpływa na teraźniejszość.

Jeżeli chodzi o różnice w sprawie liczby rozwodów w poszczególnych częściach kraju, wynikają one z historii danych terenów. Warto przypomnieć, iż tzw. Ziemie Odzyskane czy też, lepiej powiedzieć, tereny poniemieckie przez około 700 lat nie należały do Polski, nie kwitła tam ani kultura polska, ani religijność polska. Na przestrzeni tychże lat bardzo mocno okrzepła na tych terenach kultura niemiecka (także protestancka i antypolska). Z kolei Rzeczypospolitej po Il wojnie światowej (której skutki militarne były odczuwane jeszcze w latach 90 . ubiegłego wieku,

63 Por. Konferencja Episkopatu Polski, Stużyć prawdzie o małżeństwie i rodzinie, Warszawa 2009, 23.

64 Por. A. Klose, Odpowiedzialność społeczna dzisiaj, tłum. Z. Kowalska, Kraków 1999, s. 17. 
czego przykład stanowiły działania zbrojne w byłej Jugosławii ${ }^{65}$ ) zostały odebrane Kresy Wschodnie, które do dzisiaj nie wróciły do macierzy. To właśnie na wschodzie Polski w szczególnym wymiarze ugruntowywana była wartość polskości oraz zasad moralnych płynących z religijności. Charakterystyczny jest również mentalny podział obecnej Polski między tereny należące niegdyś do zaboru rosyjskiego (największa część terytorium RP) i pruskiego - w tych dwóch zaborach dominował największy terror oraz najsilniejsza walka z polskością - oraz do zaboru austriackiego, gdzie Polacy cieszyli się największą wolnością i swobodą (choć niecałkowitą) w wymiarze działań o charakterze patriotycznym. Wreszcie nie bez uszczerbku na tkance rodziny wpisał się w jej rzeczywistość, także w kontekście rozwodów, system komunistyczny. Pozornie wspierał on rodzinę, jednak w rzeczywistości pozbawiał obywateli wartości chrześcijańskich, nie dostrzegał niczego negatywnego w rozwodach, a to przecież chrześcijaństwo może stanowić podstawę uzasadnienia dla funkcjonowania osoby ludzkiej we wspólnocie ${ }^{66}$, także rodzinnej.

Powyższe fakty stanowią podstawy historyczne, które wpływają na zróżnicowanie liczby rozwodów w Polsce. Tak oto należy wskazać, iż od 1999 roku liczba ta rośnie. Jednak

Województwa Polski Południowo-Wschodniej (przede wszystkim dawna Galicja) odznaczają się z reguły wartościami o 30-40\% niższymi niż te występujące na najbardziej skłonnych do odwoływania się do rozwodów obszarach dawnych Ziem Odzyskanych. Ziemie dawnego zaboru rosyjskiego odznaczają się z kolei niższymi wartościami wskaźnika niż te obszary dawnego zaboru pruskiego, które w okresie międzywojennym wchodziły w skład państwa polskiego. Co ciekawe, w przypadku województw mazowieckiego czy łódzkiego bliskie średniej wartości wynikają głównie z zachowań ludności miast ( $w$ Warszawie i Łodzi rozpada się w ostatnich latach ok. 45\% małżeństw), ludność obszarów wiejskich charakteryzuje się

65 Por. A. Bartnicki i in., Konflikty współczesnego świata, Warszawa 2008, s. 216. 66 Por. A. Klose, Odpowiedzialność..., dz. cyt., s. 59. 
bowiem zdecydowanie bardziej tradycyjnym podejściem do trwałości związku małżeńskiego ${ }^{67}$.

Widać zatem, iż pomimo licznych zmian społecznych i gospodarczych, emigracji oraz migracji tereny wiejskie nadal pozostają (już nie $w$ tak dużym stopniu, ale jednak) tymi terenami, na których rodzina jest silną i trwałą wspólnotą w porównaniu z terenami miejskimi. Jest to spowodowane m.in. migracją w poszukiwaniu pracy. Migracja ta ma miejsce z terenów wiejskich do miejskich, a nie odwrotnie, poza takimi wyjątkami jak praca w mieście, a mieszkanie na wsi.

Stąd też tkanka współczesnego miasta polskiego jest tkanką rozdrobnioną i składającą się w dużej mierze (co nie znaczy, że we wszystkich przypadkach) z ludności przybyłej, niewykazującej większych emocjonalnych, kulturowych i rodzinnych związków z miastem, w którym pracuje. Przyjrzeć można się wybranym województwom i wskaźnikowi rozwodów na 1 tys. zawieranych małżeństw. Tak oto najwyższy wskaźnik rozwodów ogółem w roku 2000 był w województwie dolnośląskim, podobnie w roku 2010, natomiast w 2012 najwyższy wskaźnik występował w województwie zachodniopomorskim ${ }^{68}$. A zatem na przestrzeni trzech wskazanych lat najwyższy wskaźnik rozwodów ogółem miał miejsce na terenach poniemieckich; z kolei jeżeli chodzi o najwyższy wskaźnik procentowy rozwodów w miastach w tym samym okresie, to w 2000 roku było to województwo dolnośląskie, w 2010 roku oraz w 2012 warmińsko-mazurskie ${ }^{69}$. Dane dotyczące wsi z najwyższym wskaźnikiem rozwodów w podanym powyżej okresie obejmują w 2000 roku województwo lubuskie, w 2010 kujawsko-pomorskie, natomiast w 2012 roku jest to województwo zachodniopomorskie ${ }^{70}$. We wszystkich kategoriach związanych z miejscami rozwodów, a zatem przy rozpatrywaniu kategorii ogólnej, miasta oraz wsi, jeżeli chodzi o największą liczbę rozwodów, nie tylko dominują, ale wręcz jedynymi województwami są te, które przez wieki nie były w większości swojego

67 P. Szukalski, Małżeństwa binacjonalne, „Demografia i Gerontologia Społeczna - Biuletyn Informacyjny" $2013 \mathrm{nr} 3$, s. 2-3.

68 Por. P. Szukalski, Małżeństwa..., dz. cyt., s. 4.

69 Por. P. Szukalski, Małżeństwa..., dz. cyt., s. 4.

70 Por. P. Szukalski, Małżeństwa..., dz. cyt., s. 4. 
obszaru związane z kulturą i tradycją polską, a ich teren należał bądź do Niemiec, bądź do Prus Wschodnich. Przywołać należy w tym momencie miejsca, w których w tym samym czasie miała miejsce najmniejsza liczba rozwodów. Tak oto mamy tutaj do czynienia z dwoma województwami. Otóż w roku 2000 najmniejsza liczba rozwodów ogółem, w miastach oraz na wsiach, występowała w województwie świętokrzyskim, natomiast w 2010 oraz 2012 we wszystkich tych kategoriach najmniejsza liczba rozwodów obejmowała województwo podkarpackie ${ }^{71}$. Zarówno województwo podkarpackie, jak i świętokrzyskie położone są na terenach etnicznie i historycznie polskich, w których na przestrzeni wieków kształtowała się i ugruntowywała kultura oraz moralność charakterystyczna dla chrześcijaństwa, mimo iż były oraz są to tereny położone pomiędzy dużymi ośrodkami naukowymi i akademickimi, takimi jak Kraków i Lwów.

Na zakończenie powyższej analizy przyjrzeć się należy porównaniu pod tym względem dużych, najbardziej licznych województw. Według spisu ludności z 2011 roku:

najwięcej ludności faktycznie zamieszkałej liczyły województwa: mazowieckie - 5492 tys. mieszkańców, co stanowiło 14,3\% ogółu ludności kraju, śląskie - 4617 tys. (12,0\%), wielkopolskie - 3417 tys. (8,9\%) oraz małopolskie - 3406 tys. (8,8\%). Z kolei najmniej liczne województwa to: opolskie - 990 tys. osób (2,6\%), lubuskie - 1001 tys. (2,6\%) i podlaskie - 1200 tys. osób $(3,1 \%)^{72}$.

Tak oto spośród czterech najbardziej zaludnionych województw największą liczbę rozwodów ogółem w roku 2000 oraz w roku 2010 odnotowano w województwie mazowieckim, w roku 2012 w województwie śląskim ${ }^{73}$. W skład tego ostatniego województwa wchodzą zarówno tereny należące przed Il wojną światową do Polski, jak i te, które należały do Rzeszy, jak chociażby Racibórz. Z kolei najmniejsza liczba rozwodów

71 Por. P. Szukalski, Małżeństwa..., dz. cyt., s. 4.

72 Główny Urząd Statystyczny, Wyniki Narodowego Spisu Powszechnego Ludności i Mieszkań 2011. Podstawowe informacje o sytuacji demograficzno-społecznej ludności Polski oraz zasobach mieszkaniowych, Warszawa 2012, s. 7.

73 Por. P. Szukalski, Małżeństwa..., dz. cyt., s. 3. 
ogółem we wszystkich tych latach występuje w województwie małopolskim $^{74}$, posiadającym ziemie etnicznie polskie.

Widać zatem, że z jednej strony liczba rozwodów ulega zwiększeniu, z drugiej natomiast pozostają obszary w Polsce, w których małżeństwo jest wyjątkowo silne. Należy wspomnieć o jeszcze jednym bardzo istotnym czynniku, który niewątpliwie wpływa na liczbę rozwodów o wspomnianej wcześniej emigracji zarobkowej Polaków.

Na podstawie powyższych badań, ale także doświadczeń, z jakimi spotykamy się we współczesnej Polsce, należy stwierdzić, iż rozwody mają liczne przyczyny, zarówno czysto zewnętrzne, jak wspomniana emigracja, jak i wewnętrzne, np. migracja zarobkowa (wewnątrz kraju), brak religijności, kwestie związane z wychowaniem, systemem wartości oraz problemami wewnątrz małżeństwa. Pośród przyczyn o charakterze psychologicznym do rozpadu małżeństwa przyczyniać się mogą różnice zainteresowań, błędne podejście do spraw związanych z niezależnością małżonków w odniesieniach pomiędzy nimi, inne postawy względem życia towarzyskiego, jak również różnice w spędzaniu czasu wolnego i wychowaniu dzieci ${ }^{75}$. Małżonkowie posiadający różne zainteresowania mogą nie tylko nie uczestniczyć w życiu drugiej osoby pod kątem ich realizacji, ale także istnieje duże prawdopodobieństwo, iż owa różnica stanie się przyczynkiem do konfliktów i w ostateczności, jak zostało to napisane, rozwodu. Ważne jest odpowiednie traktowanie kwestii wolności w małżeństwie. Istnieją tutaj dwa rodzaje niebezpieczeństwa. Pierwsze z nich to zbyt mała przestrzeń wolności dawana sobie przez małżonków lub jednego z nich. Znane są przypadki, gdzie jeszcze przed zawarciem małżeństwa w wyniku zazdrości jedna z osób pozbawiana jest możliwości kontaktu ze środowiskiem swoich przyjaciół, znajomych, a nawet rodziny. Zdarza się, iż podświadomie osoba ta jest oskarżana o zdradę, nie może spotykać się ze swoimi koleżankami lub kolegami itd. Człowiek nie może ograniczać się jedynie do drugiej osoby, potrzebuje kontaktu z wieloma różnymi ludźmi, co stanowi ubogacenie jego życia i wpływa pozytywnie na relacje rodzinne i małżeńskie. Z drugiej strony jednak wolność może być źle wykorzystywana.

74 Por. P. Szukalski, Małżeństwa..., dz. cyt., s. 3.

75 Por. T. Borutka, Kościót wobec rozwiedzionych cywilnie zaślubionych, Bielsko-Biała 1994, s. 12. 
Zdarza się i tak, że jedna z osób życie małżeńskie i rodzinne poświęca dla życia towarzyskiego, realizacji swoich planów i marzeń, tak jakby żyła samotnie. Obie postawy są niezwykle niebezpieczne i w ostateczności niszczą relacje małżeńskie. Problemem prowadzącym do rozwodu może być również fakt różnych form spędzania wolnego czasu i braku świadomości, iż człowiek posiada moralną odpowiedzialność w wypełnianiu swoich obowiązków ${ }^{76}$. W momencie kiedy osoba decyduje się na życie małżeńskie, powinna zawsze mieć na uwadze współmałżonka i starać się z nim spędzać odpowiednią ilość czasu.

Kwestia różnych systemów wartości leżących u podstaw wychowania dzieci może przyczyniać się do decyzji o rozwodzie. Niekiedy bowiem rodzice reprezentują tak odmienne systemy wartości, że te wręcz się wykluczają, począwszy od kwestii religijnych, a skończywszy na fakcie, że jedno z małżonków jest zwolennikiem wychowania bezstresowego, a drugie nie. Wreszcie nie sposób nie wspomnieć o różnicach w podejściu do kwestii majątkowych. Otóż jeżeli jedno z małżonków pochodzi $\mathrm{z}$ rodziny dobrze sytuowanej i nie zna problemów finansowych, może od drugiej osoby wymagać standardu życia analogicznego do tego zaznanego $\mathrm{w}$ domu rodzinnym. Jeżeli druga osoba nie będzie w stanie tego spełnić, wówczas może dojść do rozwodu. Należy jednak podkreślić szczególnie mocno, iż rozwód dotyka nie tylko tych, którzy od siebie odchodzą, a więc małżonków, ale także swoimi konsekwencjami obejmuje innych członków rodziny, w tym dzieci - szczególnie te najmłodsze, często niemogące zrozumieć, dlaczego rodzice się rozstają, i często obwiniające siebie za kryzys, jaki nastąpił w małżeństwie ich rodziców.

Należy zwrócić również uwagę na fakt, że wiele spośród osób rozwiedzionych wstępuje po raz kolejny w cywilny związek małżeński. Jeżeli u takich osób religijność miała charakter jedynie obyczajowy i charakteryzowała się tym samym słabą znajomością prawd chrześcijańskich, wówczas istnieje możliwość, iż ulegną one pokusie odejścia od Kościoła i od wiary. Poprzez swój „bunt” mogą odrzucić nauczanie zarówno Kościoła, jak i Chrystusa, mówiące o nierozerwalności małżeństwa, oraz posądzić Kościół katolicki o to, że jest „nieprzejednany” w stosunku do nich ${ }^{77}$. A zatem rozwód może stać się przyczyną odejścia

76 Por. A. Klose, Odpowiedzialność..., dz. cyt., s. 21.

77 Por. J. Pałyga, Oni też chca być wierni, Ząbki 1999, s. 46. 
od Kościoła szczególnie wówczas, gdy osoby rozwiedzione nie chcą przyjąć jego nauczania, starając się narzucić własną wizję moralności. Jak zostało to już wyżej powiedziane, taka postawa wypływa z wiary, która ma jedynie charakter zewnętrzny, nie stanowi głębszej refleksji na temat życia i przesłania Kościoła oraz obowiązków, jakie spływają na wiernych. Wiara taka jest jedynie fragmentem danego obyczaju, zostaje sprowadzona do uczestnictwa w uroczystościach religijnych bez świadomości przenoszenia nauczania Kościoła do życia osobistego i rodzinnego. W Polsce charakterystyczny jest nadal wysoki procent małżeństw sakramentalnych przy jednoczesnym wzroście liczby rozwodów i wnoszenia o stwierdzenie nieważności małżeństwa. A zatem pojawia się model małżeństwa, a tym samym rodziny, jako bytu nietrwałego, skazanego na rozpad. Rodzina przestaje być tą wspólnotą, w której osoba ludzka może mieć poczucie bezpieczeństwa i przede wszystkim stałości oraz trwałości ${ }^{78}$. Wiadome jest, iż osoby pochodzące $\mathrm{z}$ domu, gdzie rodzice się rozwiedli, częściej podejmują decyzję o rozpadzie własnego małżeństwa niż ludzie pochodzący z domów, w których rozwód nie miał miejsca.

Należy też podkreślić, iż w miejsce jednej rodziny pojawia się kolejna. Otóż często jest tak, że po rozwodzie małżonkowie zakładają kolejne cywilne związki i mają dzieci zarówno z obecnego, jak i poprzedniego małżeństwa. Małżonkowie zawierający kolejny związek małżeński odrzucają miłość, jaką Stwórca kieruje w stronę osoby ludzkiej, jak również sprzeciwiają się miłości wzajemnej mającej charakter miłości małżeńskiej będącej przymierzem. Wstępując w kolejny związek małżeński, jednocześnie występują oni przeciwko samej istocie małżeństwa i odrzucają w sposób świadomy łaskę sakramentalną, która została im udzielona w małżeństwie prawowitym po to, by została utrzymana i rozwijana miłość małżeńska ${ }^{79}$. Osoby takie nie mogą przystępować do komunii świętej, stąd też nie mogą być wzorem, jeżeli chodzi o życie sakramentalne, dla swoich dzieci, zarówno z jednego, jak i drugiego związku. To powoduje często sytuacje konfliktowe - gdy rodzice chcą, by dziecko przystępowało do sakramentów świętych, jednocześnie oni sami do nich przystępować nie mogą na mocy decyzji własnej woli. Jak pisał Ojciec Święty Jan Paweł II:

78 Por. Konferencja Episkopatu Polski, Stużyć prawdzie..., dz. cyt., 26.

79 Por. T. Borutka, Kościół wobec rozwiedzionych..., dz. cyt., s. 46. 
Codzienne doświadczenie pokazuje, niestety, że ten, kto wnosi sprawę o rozwód, zamierza wejść w ponowny związek, oczywiście bez katolickiego ślubu kościelnego. Z uwagi na to, że rozwody są plagą, która na równi $\mathrm{z}$ innymi dotyka w coraz większym stopniu także środowiska katolickie, problem ten winien być potraktowany jako naglący. [...] Kościół [...] ustanowiony dla doprowadzenia wszystkich ludzi, a zwłaszcza ochrzczonych, do zbawienia, nie może pozostawić swemu losowi tych, którzy - już połączeni sakramentalną więzią małżeńską - próbowali zawrzeć nowe małżeństwo. Będzie też niestrudzenie podejmował wysiłki, by oddać im do dyspozycji posiadane przez siebie środki zbawienia [...]. Kościół jednak na nowo potwierdza swoją praktykę, opartą na Piśmie Świętym, niedopuszczania do komunii eucharystycznej rozwiedzionych, którzy zawarli ponowny związek małżeński. Nie mogą być dopuszczeni do komunii świętej od chwili, gdy ich stan i sposób życia obiektywnie zaprzeczają tej więzi miłości między Chrystusem i Kościołem, którą wyraża i urzeczywistnia Eucharystia. Jest poza tym inny szczególny motyw duszpasterski: dopuszczenie ich do Eucharystii wprowadzałoby wiernych w błąd lub powodowałoby zamęt co do nauki Kościoła o nierozerwalności małżeństwa ${ }^{80}$.

Po stronie katolików winna leżeć świadomość tego, iż wstąpienie w kolejny związek niesie ze sobą brak możliwości przyjmowania komunii świętej, sakramentu jedności pomiędzy człowiekiem a Chrystusem.

Świadomość owa wydaje się coraz mniejsza wśród tych, którzy wstępują w sakramentalny związek małżeński. Zdaje się, że nie do końca rozumieją oni (oczywiście nie wszyscy), jak dużą wagę należy przywiązywać z jednej strony do sakramentu komunii świętej, a z drugiej do sakramentu małżeństwa. Kościół na przestrzeni wieków, także w czasach współczesnych, pomaga człowiekowi w zrozumieniu sensu i wartości sakramentów, otwiera przed nim drogę do tego, by korzystał z życia sakramentalnego, jednak nie według zasad, jakie ustalą poszczególni ludzie, lecz według nauki Kościoła opartej na nauczaniu Chrystusa. Ewangelista Mateusz wyjaśnia, że rozwód nie miał miejsca w Bożym planie, a sam Jezus wobec współczesnych mu przywódców 
religijnych wyraźnie stwierdza, iż nie można oddalić swojej żony, czyli rozwód jest moralnie zły i niedopuszczalny ${ }^{81}$. To tutaj leżą źródła nauczania Kościoła na temat rozwodu, Biblia stanowi istotny punkt odniesienia i podwaliny pod wymóg nierozerwalności tej wspólnoty, jaką jest małżeństwo. Jednak współcześnie społeczeństwa zachodnie, podobnie zresztą jak społeczeństwo polskie, nie wykazują zbyt dużego zainteresowania Bożą perspektywą związaną nie tylko z małżeństwem, ale również rozwodem ${ }^{82}$. A zatem małżeństwo zostaje sprowadzone do wymiaru ludzkiego, w związku z czym ludzie uważają, mają prawo, a nawet obowiązek decydowania o momencie, w którym można owo małżeństwo zakończyć. W tym wymiarze człowiek staje na miejscu Boga, pozbawiając siebie samego punktu odniesienia, jakim jest trwałość i nierozerwalność małżeństwa. Warto zauważyć, iż systemy totalitarne dopuszczały możliwość rozwodów na długo przed tym, gdy odpowiednie zapisy prawne pojawiły się w systemach państw zachodnich. Przykładem niech będzie Rosja sowiecka, w której rozwód był osłabieniem rodziny jako nośnika wartości i sprzeciwu wobec nieludzkiego systemu komunistycznego.

W polskim systemie prawnym czasu komunizmu nie istniała możliwość separacji, co sprawiało, że małżonkowie decydowali się na rozwód, mimo iż część z nich podjęłaby decyzję o separacji, gdyby ta była możliwa. Separacja bowiem jest szansą na odrodzenie się relacji małżeńskich, nie stanowi tak jak rozwód zakończenia małżeństwa. Ojciec Święty Jan Paweł ll stwierdzał:

Różne motywy, takie jak brak wzajemnego zrozumienia, nieumiejętność otwarcia się na relacje międzyosobowe i inne, mogą w przykry sposób doprowadzić ważnie zawarte małżeństwo do rozłamu; często nie do naprawienia. Oczywiście, separację należy uznać za środek ostateczny, kiedy już wszelkie rozsądne oddziaływania okażą się daremne. Samotność i inne trudności są często udziałem małżonka odseparowanego, zwłaszcza gdy nie ponosi on winy. W takim

81 Por. J. C. Laney, Zakaz rozwodu i powtórnego małżeństwa, w: Rozwód i powtórne małżeństwo. Cztery ujęcia z perspektywy chrześcijańskiej, red. H. W. House, tłum. J. Dąbrowska-Patalon, Katowice 2004, s. 26.

82 Por. T. R. Edgar, Zakaz rozwodu i powtórnego małżeństwa. Komentarz I, w: Rozwód i powtórne małżeństwo. Cztery ujęcia..., dz. cyt., s. 56. 
przypadku wspólnota kościelna musi w szczególny sposób wspomagać go; okazywać mu szacunek, solidarność, zrozumienie i konkretną pomoc, tak aby mógł dochować wierności także w tej trudnej sytuacji, w której się znajduje; wspólnota musi pomóc mu w praktykowaniu przebaczenia, wymaganego przez miłość chrześcijańską, oraz utrzymania gotowości do ewentualnego podjęcia na nowo poprzedniego życia małżeńskiego. Analogiczny jest przypadek małżonka rozwiedzionego, który - zdając sobie dobrze sprawę z nierozerwalności ważnego węzła małżeńskiego - nie zawiera nowego związku, lecz poświęca się jedynie spełnianiu swoich obowiązków rodzinnych i tych, które wynikają z odpowiedzialności życia chrześcijańskiego. W takim przypadku przykład jego wierności i chrześcijańskiej konsekwencji nabiera szczególnej wartości świadectwa wobec świata i Kościoła, który tym bardziej winien mu okazywać stałą miłość i pomoc, nie czyniąc żadnych trudności w dopuszczeniu do sakramentów ${ }^{83}$.

Powyżej wskazano na to, iż współcześnie ma miejsce coraz częściej nie tylko rozwód, ale także wstępowanie w nowy związek, co jest konsekwencją przeobrażeń o charakterze społecznym, cywilizacyjnym, wreszcie ustrojowym i ekonomicznym ${ }^{84}$. Sytuacja ta występuje szczególnie wśród młodszego pokolenia. Są jednak i takie osoby, które bądź decydują się na wspomnianą wcześniej separację, tym samym licząc, iż będzie można w przyszłości bliższej lub dalszej uratować małżeństwo, bądź też nie decydują się na kolejny związek, zdając sobie sprawę, że mimo uzyskania rozwodu nadal pozostają w związku małżeńskim - jeśli małżeństwo miało charakter sakramentalny. W kontekście tych dwóch sytuacji można zatem mówić o kontynuacji życia rodzinnego, a na pewno o pozostaniu przy pojęciu rodziny, jakie obowiązywało przez wieki i zakładało jej nierozerwalność.

Model czy właściwiej - pojęcie rodziny uległo znacznej zmianie w imię tolerancji różnych zachowań, a przede wszystkim w imię akceptacji pragnień konkretnego człowieka kosztem innych. Fala rozwodów,

83 FC 83.

84 Por. M. Śnieżyński, Quo vadis, polska rodzino?, w: Dezintegracja rodziny, red. J. Siewiora, Tarnów 2013, s. 13. 
jaka przetacza się przez Europę, w tym również przez Polskę, spowodowana jest także „wypaleniem” jednego z małżonków, brakiem poczucia miłości w sensie jedynie emocjonalnym czy też poznaniem kogoś, z kim małżonek czuje się szczęśliwy bądź szczęśliwszy. Takie rozumowanie oparte jest jedynie na emocjach, które - co leży u ich podstaw mają charakter przejściowy. Wybory podejmowane na ich podstawie są niejednokrotnie błędne i niosą ze sobą złe konsekwencje, nie tylko dla konkretnej osoby, ale także np. dla jej najbliższych. Wchodzimy tym samym w rozumienie emocjonalne rodziny, gdzie wymaganie od siebie skazane jest na porażkę. Współczesny, postmodernistyczny człowiek powinien bowiem kierować się swoimi pragnieniami oraz unikać wysiłku, również w relacjach z innymi, jednocześnie osłabiając więzi rodzinne będące podstawą, która łączy poszczególnych członków tej wspólnoty ${ }^{85}$. Jeżeli pojawia się więc problem w życiu małżeńskim, należy go nie rozwiązać, lecz zostawić, a najlepszą drogą do osiągnięcia tego celu jest rozwód.

Obok coraz częściej występujących rozwodów spotkać się także można z tzw. tolerancją obyczajową, która wymaga osobnego omówienia.

\section{Tolerancja obyczajowa - fakt społeczny czy pojęcie abstrakcyjne, ratunek czy zagrożenie dla rodzin?}

Na przestrzeni wieków, w okresie wojen, w czasie pokoju, w sytuacji sprzyjającej rodzinie, ale także tej, która jej zagrażała, istniała ugruntowana społecznie i, można powiedzieć, mentalnie obyczajowość. Co więcej wartości te były bardzo silnie związane z rodziną, która była pierwszą ich nauczycielką. O ile kiedyś rodzina tworzyła niezwykle silną komórkę społeczną, wiele osób zawierało małżeństwa, o tyle po 1989 roku, roku przemian, sytuacja ta uległa zmianie. Jeszcze w 1988 roku w rodzinnych gospodarstwach domowych żyło 91 proc. całej ludności Polski ${ }^{86}$, obecnie natomiast coraz więcej pojawia się wolnych związków, konkubinatów itd. Ma to swoje źródło w tolerancji obyczajowej, która w Polsce

85 Por. M. Śnieżyński, Quo vadis.., dz. cyt., s. 22.

86 Por. Główny Urząd Statystyczny, Rodzina w świetle wyników NSP 1988. Narodowy spis powszechny, Warszawa 1991, s. 40 (Materiały i Opracowania Statystyczne). 
zaczęła być coraz silniejsza po zmianach we wspomnianym roku 1989. Przyczyną tego faktu było m.in. otwarcie się na wzorce pochodzące z Europy Zachodniej, także te negatywne. Wydaje się, że Polacy w znacznej mierze właśnie te negatywne wzorce przyjmują, wręcz fascynując się nimi. Oprócz tego zaczęto budować w 1989 roku, formalnie od grudnia 1989, państwo, które nie było oparte na zasadach moralnych, a ci, którzy te zasady głosić chcieli i je głosili, byli bezpodstawnie krytykowani, na czele z Ojcem Świętym Janem Paweł II.

A to właśnie papież Polak mówił do swoich rodaków w 1995 roku w Skoczowie:

Nasza Ojczyzna stoi dzisiaj przed wieloma trudnymi problemami społecznymi, gospodarczymi, także politycznymi. Trzeba je rozwiązywać mądrze i wytrwale. Jednak najbardziej podstawowym problemem pozostaje sprawa ładu moralnego. Ten ład jest fundamentem życia każdego człowieka i każdego społeczeństwa. Dlatego Polska woła dzisiaj nade wszystko o ludzi sumienia! Być człowiekiem sumienia, to znaczy przede wszystkim w każdej sytuacji swojego sumienia słuchać $\mathrm{i}$ jego głosu w sobie nie zagłuszać, choć jest on nieraz trudny i wymagający; to znaczy angażować się w dobro i pomnażać je w sobie i wokół siebie, a także nie godzić się nigdy na zło, w myśl słów św. Pawła: „Nie daj się zwyciężyć złu, ale zło dobrem zwyciężaj!” (Rz 12, 21). Być człowiekiem sumienia, to znaczy wymagać od siebie, podnosić się z własnych upadków, ciągle na nowo się nawracać. Być człowiekiem sumienia, to znaczy angażować się w budowanie królestwa Bożego: królestwa prawdy i życia, sprawiedliwości, miłości i pokoju, w naszych rodzinach, w społecznościach, w których żyjemy, i w całej Ojczyźnie; to znaczy także podejmować odważnie odpowiedzialność za sprawy publiczne; troszczyć się o dobro wspólne, nie zamykać oczu na biedy i potrzeby bliźnich, w duchu ewangelicznej solidarności: „Jeden drugiego brzemiona noście” (Ga 6,2). Pamiętam, że powiedziałem te słowa w Gdańsku podczas odwiedzin w 1987 roku na Zaspie ${ }^{87}$.

87 Jan Paweł Il, Homilia w czasie Mszy św. odprawionej na wzgórzu Kaplicówka, Skoczów, 22 maja 1995, w: Jan Paweł Il, Pielgrzymki do Ojczyzny. Przemówienia..., dz. cyt., s. 844. 
Podstawą moralności jest sumienie. Wszędzie tam, gdzie jest ono odpowiednio ukształtowane, nie będzie tolerancji dla zachowań obyczajowych, które są moralnie złe. Ojciec Święty w pierwszej połowie lat 90. prosił o moralność w życiu społecznym, także w życiu rodzinnym. Wydaje się, iż naród, który był i nadal pozostaje dumny z papieża Polaka, jednocześnie traktuje go jako kogoś obcego - wprawdzie zna go $\mathrm{z}$ imienia, potrafi nawet wymienić, $\mathrm{w}$ jakim okresie żył, ale nie kieruje się jego wezwaniami i nauczaniem.

Należy w tym kontekście wspomnieć o mieszkaniu par przed ślubem, stosowaniu środków antykoncepcyjnych, zgodzie na zapłodnienie in vitro, akceptacji związków homoseksualnych, nawet zgodzie na adopcję przez te pary dzieci, wreszcie o coraz liczniejszych rozwodach, zdradach itd. O wielu spośród tych aspektów będzie jeszcze mowa, jednak w tym miejscu należy je wskazać, ponieważ to właśnie one charakteryzują od lat tolerancję obyczajową, która jest faktem społecznym. Coraz więcej par decyduje się na mieszkanie przed ślubem, tłumacząc to m.in. względami finansowymi. Często są to osoby pochodzące z domów katolickich i wychowane w tradycji katolickiej, a rodzice tolerują ich zachowania, nie sprzeciwiając się im. Owe wzorce obyczajowości, a raczej tolerancji, charakteryzują się nastawieniem egoistycznym: oto para ludzi coraz częściej żyje tylko dla siebie, pozostawiając poza kręgiem własnych zainteresowań rodzinę, ale także społeczeństwo. Faktem natomiast jest, że nie można przeciwstawiać człowieka społeczeństwu i odwrotnie ${ }^{88}$. Każde takie przeciwstawienie jest jednocześnie zagrożeniem dla rodziny.

Warto podkreślić, iż szeroko rozumiana tolerancja obyczajowa bardzo często jest argumentowana dobrem rodziny: osoby chcące wstąpić w związek małżeński muszą przed ślubem „sprawdzić się”, czy są w stanie razem przebywać, mieszkać itd.; środki antykoncepcyjne stanowią obronę przed niechcianym dzieckiem, gdyż rodziców może nie stać na jego wychowanie, a jego pojawienie się na świecie może naruszyć ich zawodową karierę. Takich przykładów można by opisywać wiele. Jednocześnie dochodzi do pewnego paradoksu - otóż z jednej strony coraz więcej młodych osób mieszka ze sobą przed ślubem, z drugiej wydłużają one

88 Por. M. Włosiński, Pedagogiczne odkrywanie prawdy w ujęciu Jana Pawła II, w: M. Włosiński, Świat wartości, Włocławek 2009, s. 56. 
czas przed zawarciem małżeństwa, tłumacząc to prawem do dysponowania własnym czasem, prawem do rozrywki ${ }^{89}$, brakiem chęci do podjęcia życiowego zobowiązania.

W omawianym kontekście pojawia się jeszcze sprawa związana z ideologią gender. Otóż należy zauważyć, iż ideologia ta, oparta na całkowitej tolerancji obyczajowej, dopuszcza wszelkiego rodzaju zachowania o charakterze seksualnym kierowane do osób w różnym wieku, także małoletnich, a nawet dzieci. Co więcej - twórcy tej ideologii i jej propagatorzy nie tylko tolerują różne zachowania, ale wręcz je promują i uczą w przedszkolach oraz szkołach. Przykładem jest chociażby wskazywanie dzieciom na przyjemność czerpaną z masturbacji, a model rodziny, gdzie ojciec jest tym, który opiekuje się dziećmi, stanowi obraz dominacji oraz opresji ${ }^{90}$.

Tolerancja obyczajowa oparta na postmodernizmie i z niego wypływająca charakteryzuje się podobnymi do niego cechami. Otóż postmodernizm przedstawiany jest jako „miękki”, „elastyczny”, czyli otwarty, jak również nieformalny i oczywiście tolerancyjny, szukający porozumienia. Tak naprawdę zaś jest on zamknięty i wojowniczy. Z jednej strony istnieje teoretyczna wolność wyboru, $\mathrm{z}$ drugiej natomiast - narzucenie własnej interpretacji tegoż wyboru' ${ }^{91}$. A zatem w imię tolerancji mamy do czynienia ze swoistego rodzaju terrorem moralnym i obyczajowym, który wpływa negatywnie na rodzinę, będąc dla niej istotnym zagrożeniem. Należy podkreślić, iż mentalność postmodernistyczna, na której opiera się tolerancja obyczajowa, nie jest mentalnością przeszłą, tą, która minęła wraz z upadkiem totalitarnych systemów politycznych czy też zmianami historycznymi o innym zakresie. Dlatego też tolerancja obyczajowa jest coraz silniejszym faktem społecznym.

Warto podkreślić, iż współczesna rodzina boryka się z licznymi problemami wynikającymi ze zmieniającego się systemu wartości w otaczającym ją świecie. To właśnie w rodzinie, tak jak w soczewce, widać pojawiające się coraz to nowe trendy, które pod hasłami tolerancji, zarobku, poprawy bytu, wolności sprawiają, że najmniejsza komórka społeczna

89 Por. M. Śnieżyński, Quo vadis..., dz. cyt., s. 25.

90 Por. Pełnomocnik Rządu do Spraw Rodziny, Raport o sytuacji polskich..., dz. cyt., s. 158.

91 Por. M. A. Peeters, Gender - światowa norma polityczna i kulturowa. Narzędzie rozeznania, tłum. L. Woroniecki, Warszawa 2013, s. 120. 
ulega coraz silniejszemu rozkładowi, szczególnie jeśli chodzi o więzy rodzinne, obyczajowość, moralność. Dlatego też istotne jest podjęcie refleksji etycznej nad stanem, w jakim obecnie znajduje się polska rodzina. 